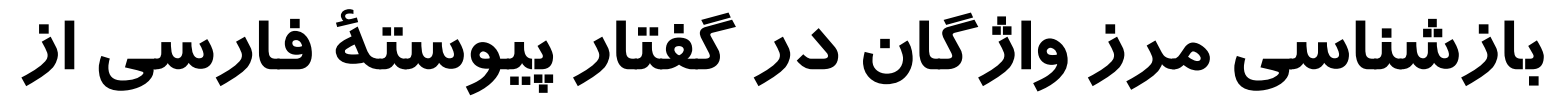

(s9)

وحيد صادقى

كروه زبان انگليسى، دانشكده علوم انسانى، دانشعاه بينالمللى امام خمينى، ايران

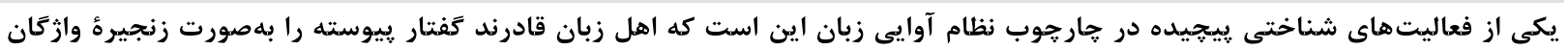

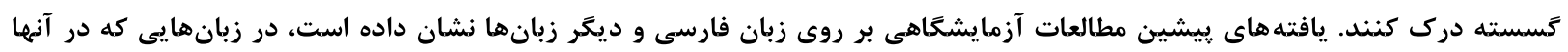

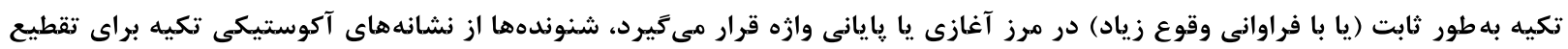

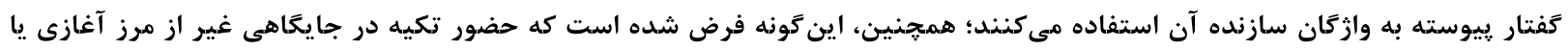

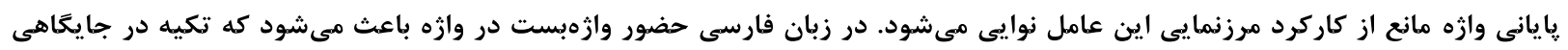

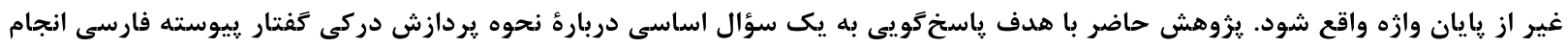

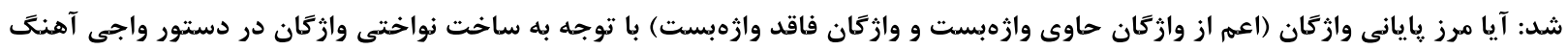

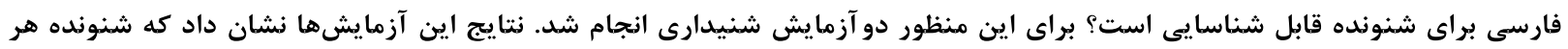

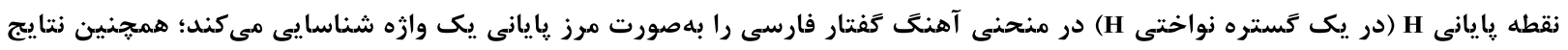

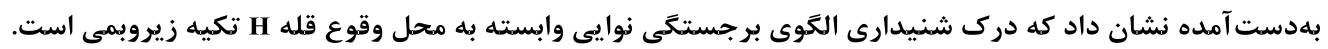

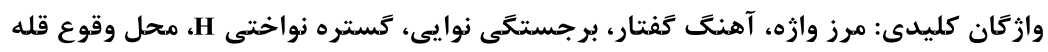

\section{Word segmentation in Persian continuous speech using FO contour}

\author{
Vahid Sadeghi \\ linguistics Department of English language and linguistics \\ Imam Khomeini International University, Iran
}

\begin{abstract}
Word segmentation in continuous speech is a complex cognitive process. Previous research on spoken word segmentation has revealed that in fixed-stress languages, listeners use acoustic cues to stress to de-segment speech into words. It has been further assumed that stress in non-final or non-initial position hinders the demarcative function of this prosodic factor. In Persian, stress is retracted to a non-final position in words containing enclitic affixes.

The present research explores the question as to whether Persian listeners are able to identify word boundaries given the tonal structure of words in Persian phonology or not. The paper was also intended to investigate to what extent Persian native speakers use $H$ peaks to identify word stress pattern. Two perceptual experiments were conducted in this regard. Given the tonal structure of words in utterance nonfinal position in Persian, it was hypothesized that listeners are likely to identify the end of a high plateau as a cue to word boundary. In addition, given that peaks in utterance non-final position are delayed, it was
\end{abstract}

* Corresponding author *نويسنده عرهددار مكاتبات 
further hypothesized that perceived prominent is likely to be attributed to a syllable that precedes another syllable carrying a pitch peak.

The basic stimulus for the first experiment was a nonsense sequence of nine " $\delta A$ " syllables with equal duration $\left(\left[\delta \mathrm{A}_{1} . \delta \mathrm{A}_{2} . \delta \mathrm{A}_{3} . \delta \mathrm{A}_{4} . \delta \mathrm{A}_{5} . \delta \mathrm{A}_{6} . \delta \mathrm{A}_{7} . \delta \mathrm{A}_{8} . \delta \mathrm{A}_{9}\right]\right)$ across the syllables. The peak was located at the beginning of the consonant in $\left[\delta \mathrm{A}_{4}\right]$ in the stimulus. The duration of the $\mathrm{H}$ plateau following the $\mathrm{H}$ peak was varied continuously to create 6 different stimuli with varying temporal plateau. The stimuli were presented randomly to 10 native speakers of Persian. The participants were asked to chunk the sequence of identical syllables they hear into two parts as if they were two independent words. They were also asked to identify the most prominent syllable in a separate identification test. The results showed that the ending point of a high $\mathrm{H}$ plateau acts as a prosodic cue to word boundary detection in Persian. For example, when the end of the $H$ plateau was located on the end of the vowel in $\delta A_{4}$, listeners identified the end of $\delta A_{4}$ as boundary between two hypothetical words. However, when the end of the plateau was located on the end of the vowel in $\delta A_{5}$ or the beginning of the consonants in ${ } \delta \mathrm{A}_{6}$ listeners identified the end of $\delta \mathrm{A}_{5}$ as the word final boundary. The results of this experiment further revealed that listeners are sensitive to the position of $H$ peaks to identify within-word position of prominence in Persian. Listeners consistently identified $\delta \mathrm{A}_{3}$ as the most prominent syllable as this syllable preceded $\delta \mathrm{A}_{4}$ on which the peak was located, and the rate of their identification was not affected by the duration of $\mathrm{H}$ plateau following the pitch peak.

In the second experiment, listeners' ability to use F0 contour as a cue to word boundary was tested on resynthesized speech in which the spectral properties of the signals were intentionally deformed. The results replicated the findings previously obtained for the first experiment, indicating that the end of a high plateau acts as a robust cue to word boundary detection in Persian.

Keywords: word boundary, intonation, prosodic prominence, $H$ plateau, position of $H$ peaks

$$
\begin{aligned}
& \text { شنونده با استفاده از اطلاعات زنجيرهاى مانند مشخصههاى }
\end{aligned}
$$

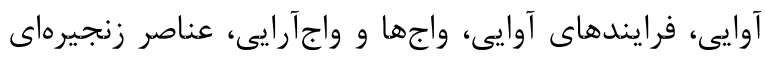

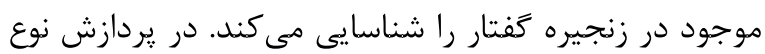

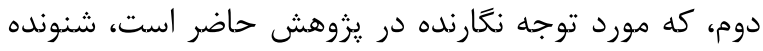

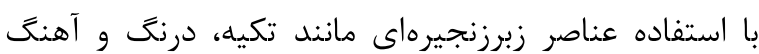

$$
\begin{aligned}
& \text { مرز آكوستيكى بين واحدهاى نوايي بزركتر از واج در زنجيره }
\end{aligned}
$$

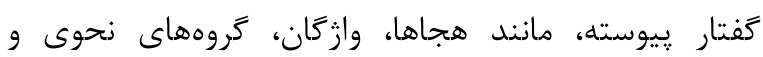

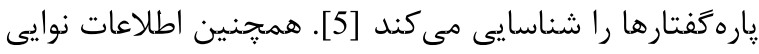

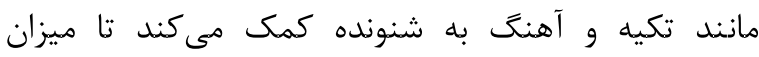

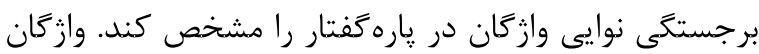

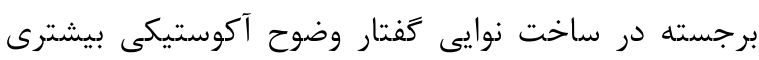

$$
\begin{aligned}
& \text { دارند [14]، ذخيرهسازى و بازيابى آنها در حافظه با سهولت وضوات و } \\
& \text { سرعت بيشترى انجام مىشود [13] و بيش از ساير وازگًان } \\
& \text { توجه شنونده را بهسوى عناصر اطلاعى جديد در ساخت } \\
& \text { كفتمان جلب مى كنند [14]. } \\
& \text { تكيه واگانى يكى از مهمترين عوامل مؤثر بر تقطيع }
\end{aligned}
$$

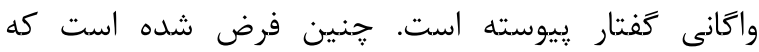

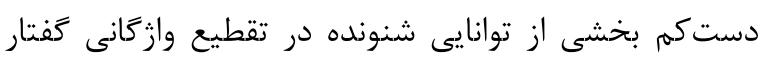

$$
\begin{aligned}
& \text { ييوسته به دانش وى در ارتباط با ساخت عروضى جمله } \\
& \text { مرتبط است [7]. اين دانش عروضى به شنونده كمك مي كى كند } \\
& \text { حتى بههنگام عدم دسترسى به اطلاعات زبانشناختى، كفتار }
\end{aligned}
$$

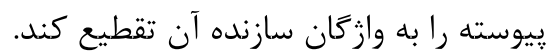

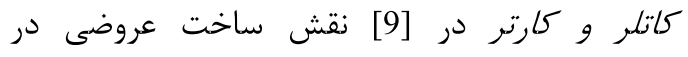

$$
\begin{aligned}
& \text { بازشناسى كَتار ريوسته را با طرح فرضيهاى با عنوان فرضيه }
\end{aligned}
$$

\section{dodêم-1}

شنونده در فرايند بازشناسى گفتتار بيوسته، بازنمود بيوسته

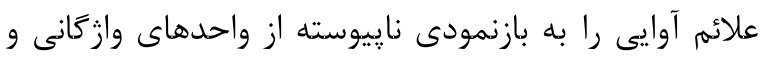

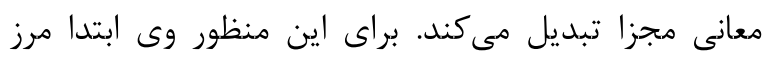

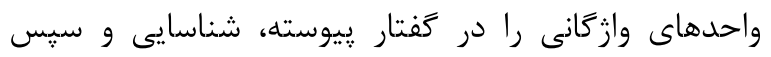
الكوى آوايى هر واحد وازگًانى را با انطباق با الكوى آوايى مرجع براى آن واحد در ذهن خود بازشناسى مى كند. تقطيع وازگًانى كَفتار ييوسته فرايندى حوزهاى است كه كه مستلزم يردازش در سطوح مختلف زبانى از جمله يردازشهاى آوايى، واجشناختى، صرفى، نحوى، معنايى و كاربردشناختى است است إنى

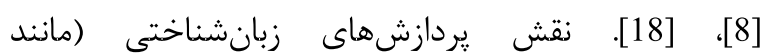
يردازشهاى صرفى، نحوى، معنايى و واجى) در شناسايى

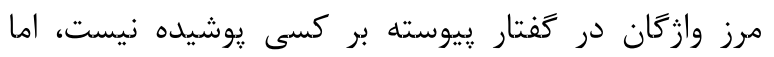
شنونده قادر است، حتى در بافتهاى زبانى كه به اطلاعات زبانشناختى دسترسى ندارد (مانند محيطهاى يرسر و صدا

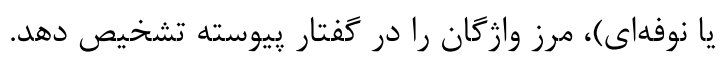

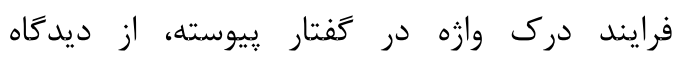
واجشناختى، مستلزم دو دسته يردازش واجى است: يكى

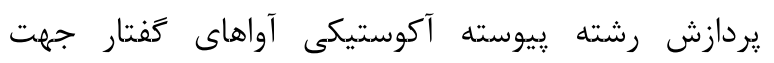

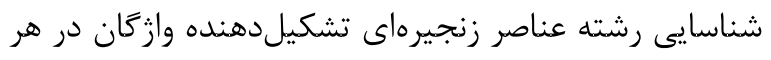

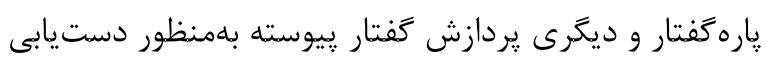

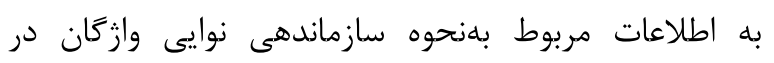

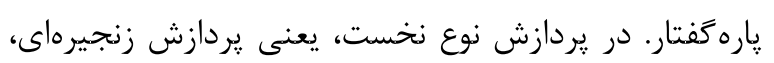


حضور دارد، مدت زمان بيشترى به طول مىانجامد. كاتلر و

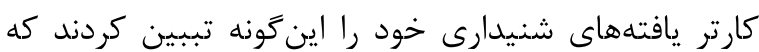

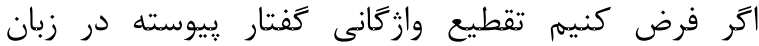

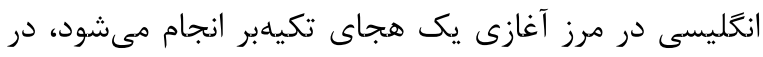
آن صورت اين تفاوت در مدت زمان بازيابى وازئان قانى قابل توجيه است. در زنجيرههايى مانند mintayve با توجه به حضور دو هجاى قوى در سطح زنجيره، فرايند تقطيع وازكانى دو بار فعال مىشود؛ ولى در زنجيرههايى مانند كه mintef

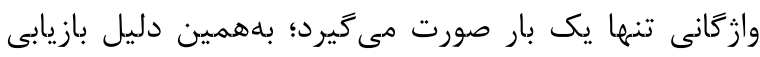
وازه mint در سر mintef سريعتر از mintayve انجام مىشود. كاتلر و باترفيلد در يك آزمايش ديكرى بر روى زبان انكليسى نشان دادند كه شنوندهها مرز وازًان را در كفتاري بِيوسته از روى محل حضور هجاهاى قوى در زنجيره آوايى

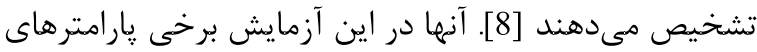

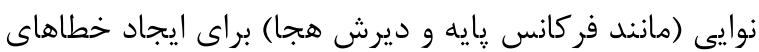
شنيدارى بلصورت عمدى دستكارى كردند و دريافتند كه خطاى درج اشتباه يك مرزوازه اغلب قبل از هجاهاى قوى دئ داء

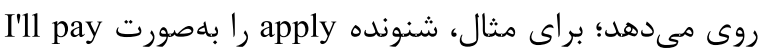
درك مى كند. در مقابل، حذف اشتباه يك مرزوازه قبل از مناز a هجاهاى ضعيف صورت مى گيرد؛ براى مثال شنونده،

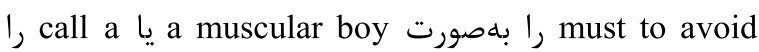
بلبصورت caller درك مى كند. اين نتايج براى زبانهاى ديكر نيز تزارش شده است.

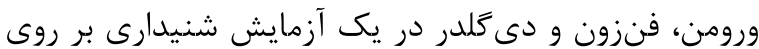
زبانهاى هلندى و فنلاندى كه در آنها تكيه اغلب بر رئ روى درى

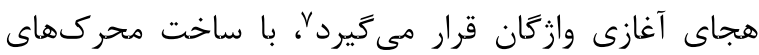
مصنوعي بىمعنى شامل زنجيرههاى سههجايي تكراى از نوع

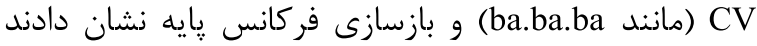
كه شنونده هر ناحيهاى از زنجيرههاى بازسازىشده مصنوعى إنى را كه با افزايش سطح فر كانس بايه همراه باشد، بهاعنوان مرز

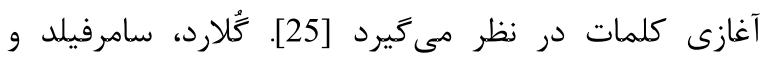
كوگلر با انجام آزمايشهاى توليدى-شنيدارى بر بر روى إنى ساختهاى نحوى مبهم در زبان آلمانى دريافتند كه آنهائ

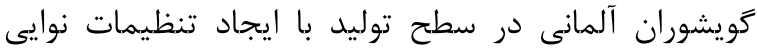

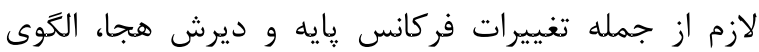
توليدى جملات مبهمم را بهنحو مؤثرى متناسب با خوان برانش

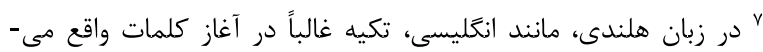

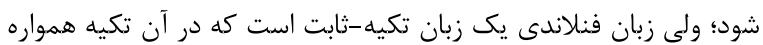
به طور ثابت بر روى هجاى آغازى وازه قرار مي كيرد.
راهبرد تقطيع عروضى' تببين كردهاند. اين فرضيه بهطور مشخص بيان مى كند كه اتر در زبانى، جايكاه تكيه در سطح

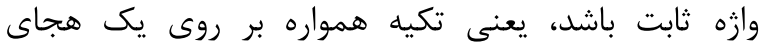

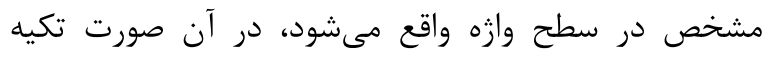
كاركرد تحديدى دارد و مى دوتواند بهطور بالقوه مرز آوايى

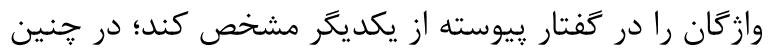

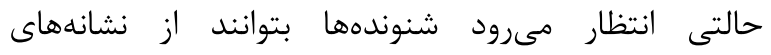
آكوستيكى تكيه براى تقطيع كَفتار ييوسته به وازگًان سازنده

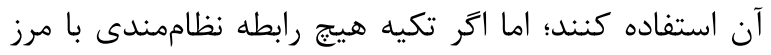
هجايى درون وازه نداشته باشد، در آن صورت نبايد انتظار داشت كه تكيه در فرايند تقطيع وازگكانى كفتار وييوسته مؤثر باشد. بر اين اساس در زبانهاى تكيه-ثابت مَ كه در آنها تكيه بهطور ثابت در آغاز وازه (مثل فنلاندى، مجارى، جكىى) قرار

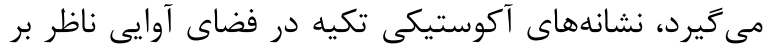

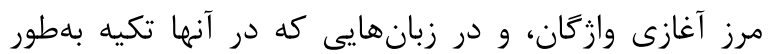
ثابت در پايان وازه (مثل فرانسوى، فارسى) قرار مى زئيرد،

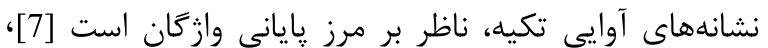
[11]، [24]. بر اساس فرضيه راهبرد تقطيع عروضى، تكيه

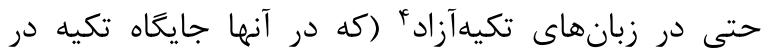
سطح وازه ثابت نيست) نيز كاركرد تحديدى و مرزنمايى دارد

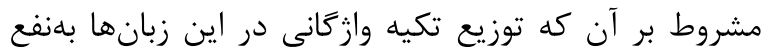

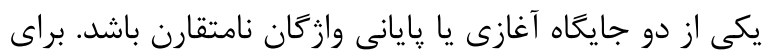

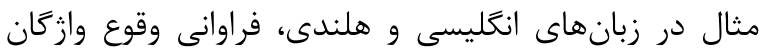

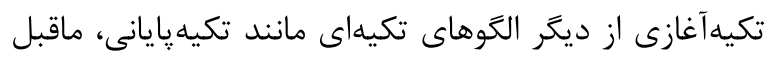

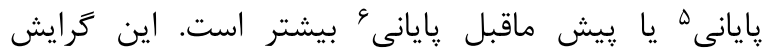

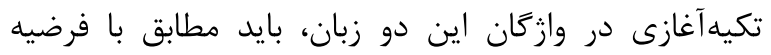
مطرحشده بر بازشناسى وازَّانى كفتار وييوسته مؤثر باشد.

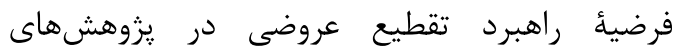
آزمايشكاهى تأييد شده است. كاتلر و كارتر در يكى درديع آزمايش شنيدارى بر روى زبان انخليسى [9] ثابت كردند كه يردازش

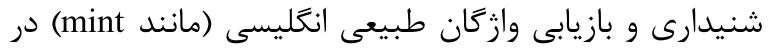
زنجيرههاى آوايي دوهجايي بىمعنى (مانند mintayve و

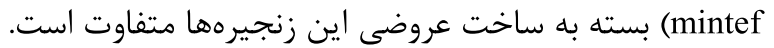

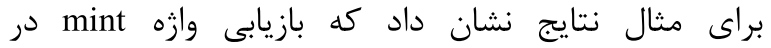
mintayve كه در آن هر دو هجا قوى هستند، نسبت به كه تنها يك هجاى قوى (هجاى آغازى) در آن آن

\footnotetext{
${ }^{1}$ Metrical segmentation strategy

${ }^{2}$ Demarcative

${ }^{3}$ Fixed stress languages

${ }^{4}$ Free stress languages

${ }^{5}$ Penultimate

${ }^{6}$ Antepenultimate
} 
بى جن خان در آزمايشى مشابه با آزمايش كاتلر و كارتر نشان

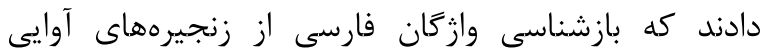

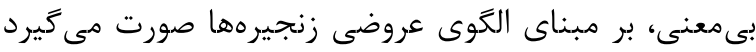

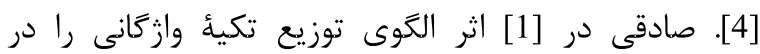
ابهامزدايى از عبارات مبهم فارسى در آزمايشهاى توليدى شنيدارى بررسى كرد. عبارت مبهم اين يزوهش شامل

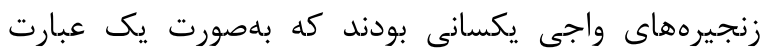

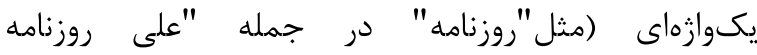

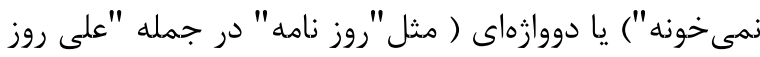

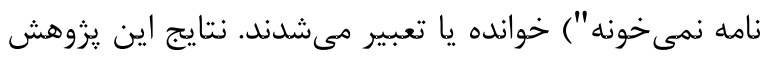
نشان داد كه نقش نشانههاى نوايى در ابهامزدايى از اين عبارات در سطح توليد و درك كفتار با يكديكر متفاوت است؛ ندان

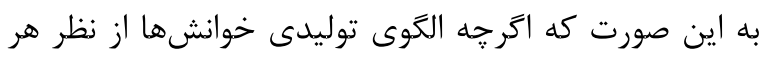
سه نشانه نوايي فركانس بايه، ديرش و وقفه با هم متفاوت، ولى تشخيص خوانشها تا حد زيادى به تغييرات فركانس

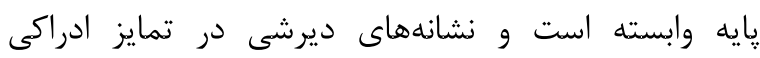
خوانشها تأثير جندانى ندارند.

بهطور خلاصه با اتكا به يافتههاى يزوهشى بالا

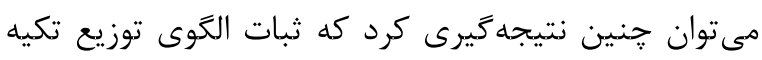

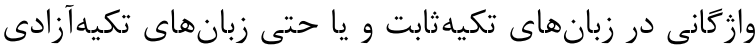

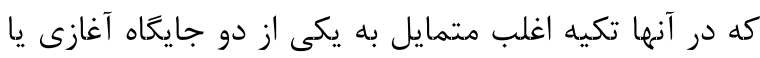

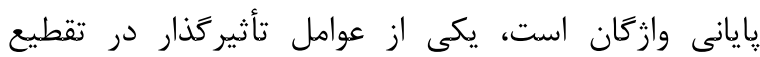

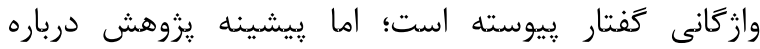

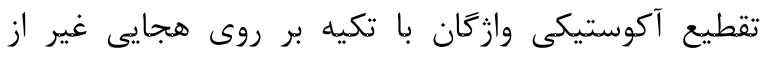

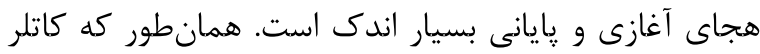
[7] نيز اشاره كرده، جون تقطيع و بازشناسى وازَكانى كفتار، مستلزم يردازش بيوسته اطلاعات آكوستيكى است، حضور

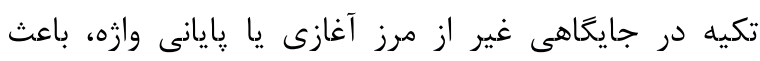
يِيجيدهترشدن اين فرايند مىشود. در زبان فارسى، وندهاى

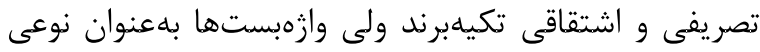
ديكر از وندهاى غيراشتقاقى فاقد تكيه هستند و بنابراين وقتى وازمبستها به وازه اضافه مىشوند، جايگاه تكيهوازه تغيير نمى كند. به اين ترتيب حضور وازهبست در سطح وازهن

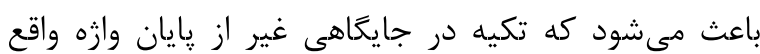
شود. ازاينرو بديهى است كه نشانهاى آكوستيكى تكيه در فضاى آوايى قادر به تشخيص مرز آكوستيكى وازئان حاوى إنى وازهبست نيستند. با اين وجود با توجه به ساخت نواني نواختى وازكان در دستور واجى آهنگ فارسى مىتوان بِيشبينى كرد

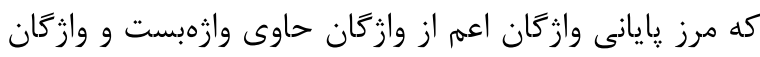

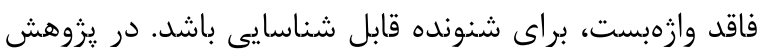

معنايى مورد نظر تغيير مىدهند و در سطح درى كَفتار از تغييرات ديرش و فركانس קايه براى تشخيص خوانشهاى

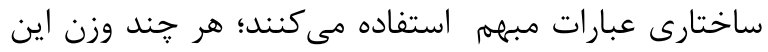
يارامترها در تشخيص خوانشهاى نحوى به يك اندازه نيست

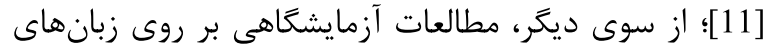
مختلف نقش مؤثر عوامل آهنكى در تقطيع وازگكانى كفتار بيوسته را ثابت كرده است [15]، [19] و [20]. يافتههاى اين دران مطالعات نشان داده شناسايى مرز واحدهاى نوايى در كفتار

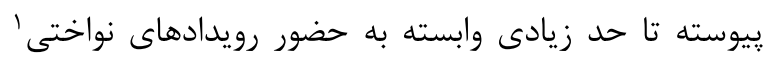

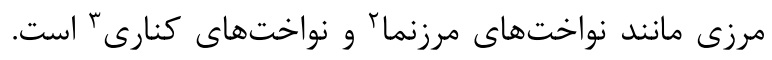

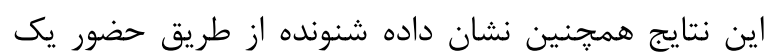

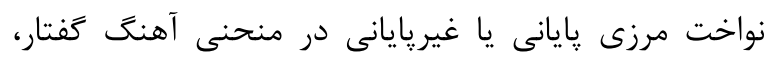

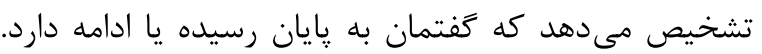
افزون بر اين، يافتههاى برخى مطالعات نشان داده شنونده قادر است حتى درصورت تخريب ساخت فركانسى سيكنال

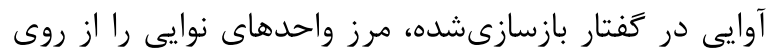

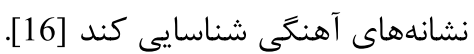
تكيةٔ زيروبمى، يكى ديخر از رويدادهاى آهنتى مهمه

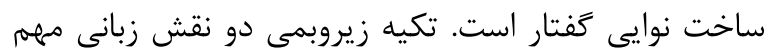

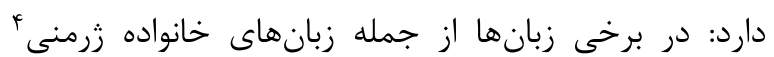

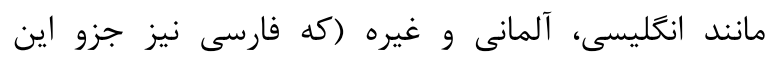

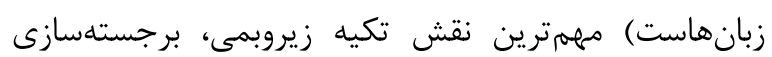

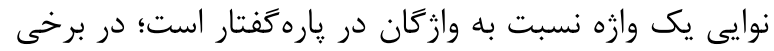

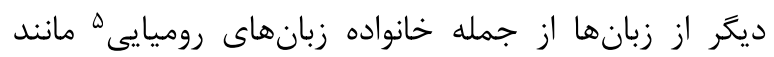

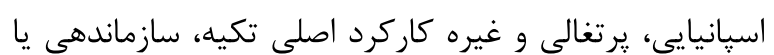

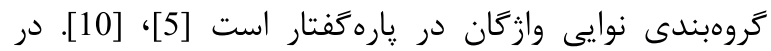

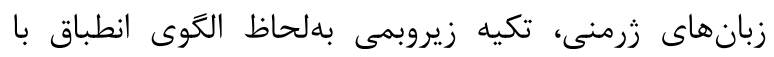
ساخت زنجيرهاى كفتار منطبق بر هجاى زئى تكيهبر وازيه برجسته است؛؛ اما در زبان هاى روميايى، تكيه زيروبمى با مرز

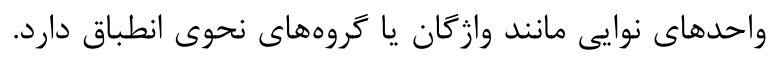

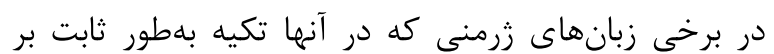

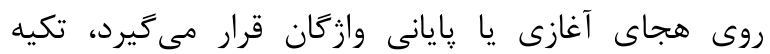

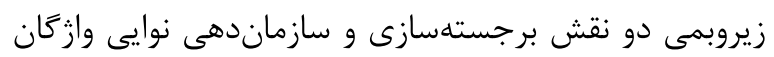
در يارهكفتار را بهطور همزمان انجام مى دهدي

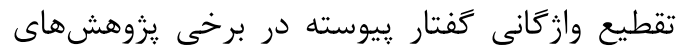

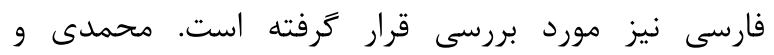

${ }^{1}$ Tonal events

2 Boundary tones

${ }^{3}$ Phrase accents

${ }^{4}$ Germanic languages

${ }^{5}$ Romance languages 
پإيانى وازه واقع مىشوند. تكيه زيروبمى در زبان فارسى تكيه

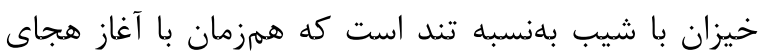
تكيهبر شروع و در هجاى بعد از هجاى تكيهبر رايان مى يابد

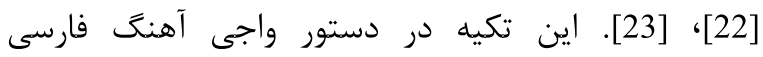

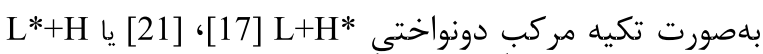
[3] بازنويسى و توصيف شده است (در ادامه، نكارنده از الكوى LF+H براى توصيف ساخت نواختي تكيه زيروبمي

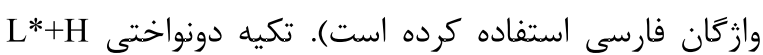
براى بازنويسى ساخت نواختي وازٔمان جندهجايى با تكيه

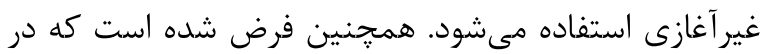

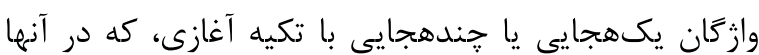
فضاى زنجيرهاى كافى براى تظاهر آوايى نواخت L وجود

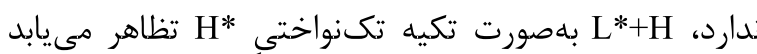

.[22] ‘[21]
حاضر نقش نواخت كنارى H- در بازنمود واجى كروه تكيهاى

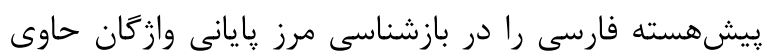
وازثبست بررسى مي كنيه.

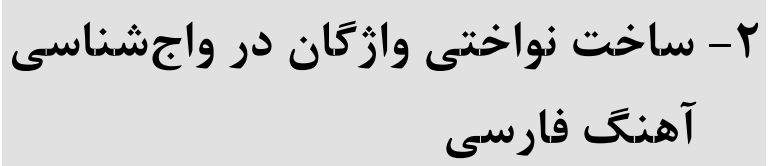
آهنگ فارسى از دو سطح سلسلهمراتبى نوايى، يعنى كروه تكيهاى (AP) و كروه آهنگ (IP) تشكيل مىشود [2]، [17]، [21]، [22]، [23]. هر كروه تكيهاى شامل يك وازه هحتوايى و وازمبستهاى وابسته به آن است. كروه آهنَ از تركيب يكى يا جند كروه تكيهاى ساخته مىشود. ساخت نواختى يك كروه تكيهاى شامل يك تكيه زيروبمى و يك نواخت كنارى است [3]، [17]، [21]، [22]، [23]. تكيه زيروبمى بر روى زئس هجاى تكيهبر وازوه (يا كروه تكيهاى) و نواخت كنارى در مرز

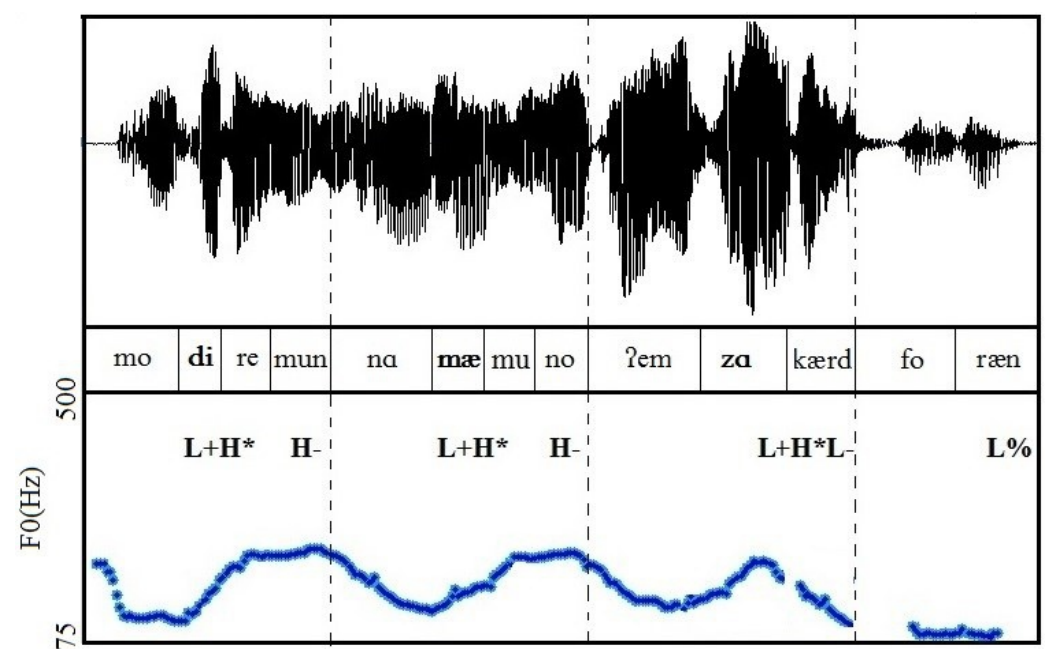

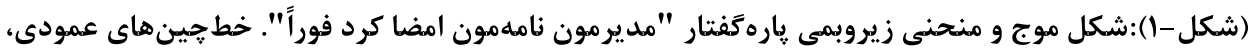

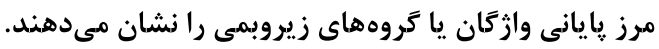

(Figure-1): Waveform and F0 contour of the utterance /mo'dir-emuin na'mæ-mun-o ?em'za кæp $\delta$ foræn/ "our manager signed our letter right away". Dashed lines indicate boundaries between words or accentual phrases.

انخيزه اصلى وجود نواخت كنارى در ساخت آهنگ

كفتار فارسى، تفاوت نواخت كنارى گروه تكيهاى هسته و

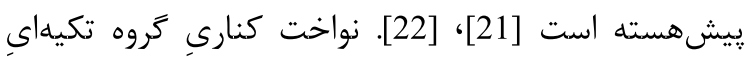

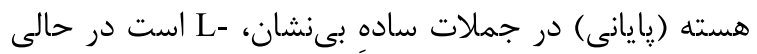

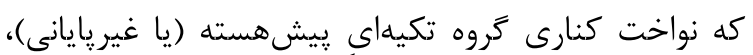

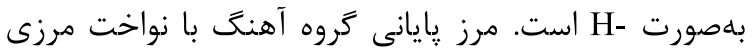

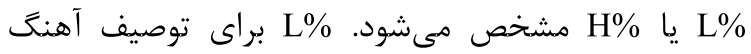

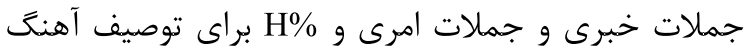
سؤالات بلى اخير استفاده مىشود [21]، [22]

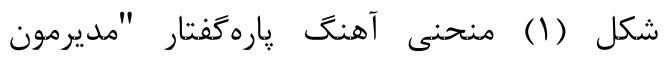
mo'dir-emuin na'mæ-mun-) "نامdمونُ امضا كرد فوراً
در هر زروه تكيهاى، در حد فاصل بين محل وقوع

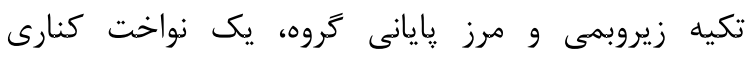

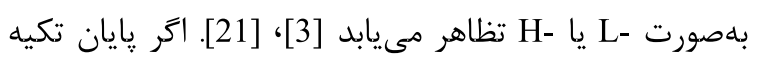

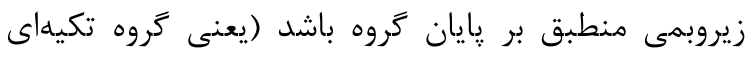

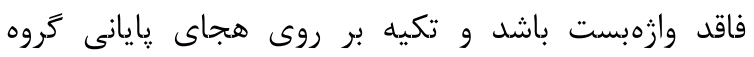
تكيهاى قرار كيرد)، نواخت كنارى بر روى هجاى تكيد

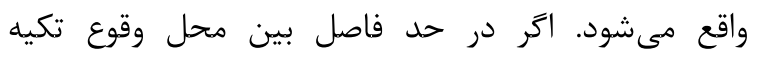

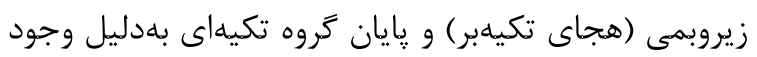

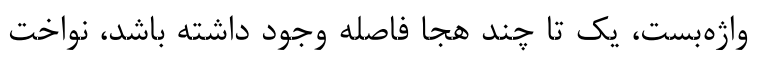
كنارى بر روى تمامى هجاهاى بدون تكيه بعد از هجاى تاى هاه

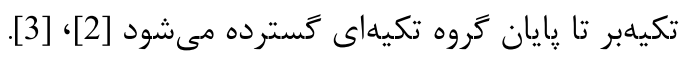


اين هجا) تظاهر مىيابد، ديركرد قله ' ناميده مىشود. اين

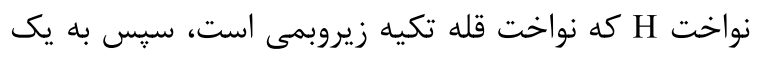

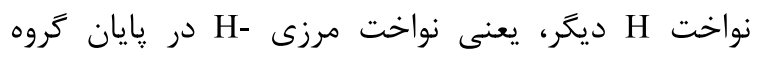

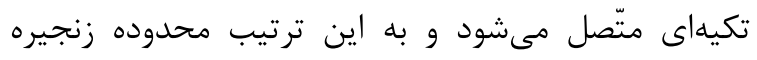

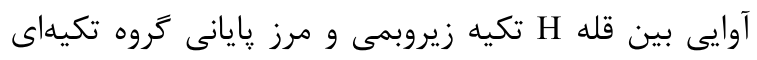

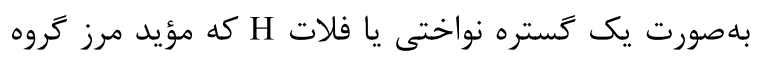
تكيهاى است، تظاهر مىيابد.

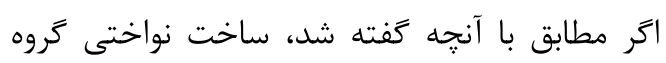

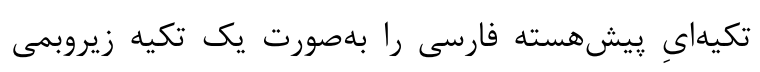

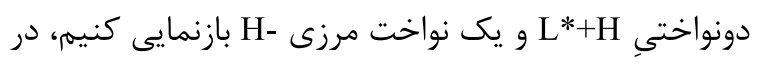

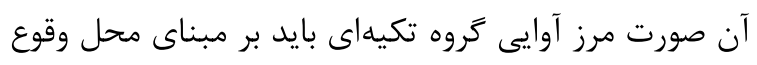
نواخت كنارى H- در منحنى آهنگ تفتار فارسى براى

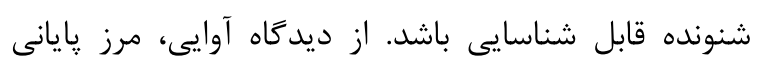

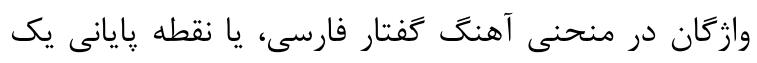

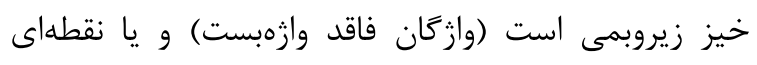

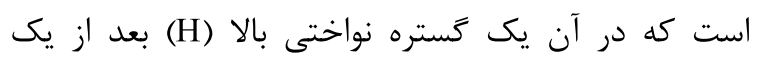

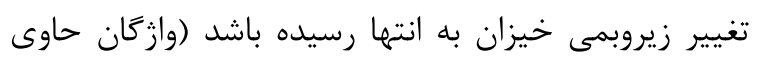

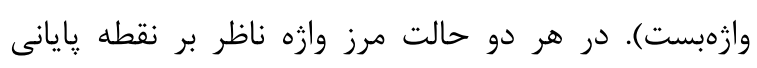

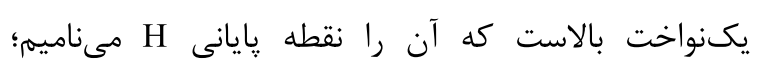

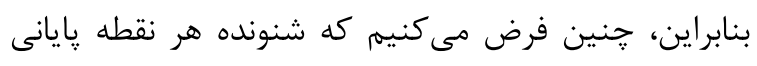

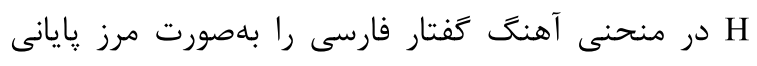

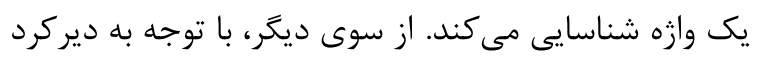

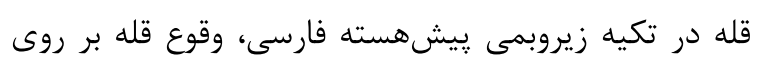

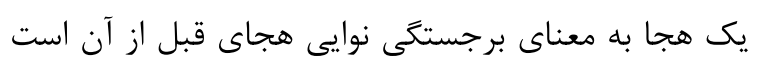

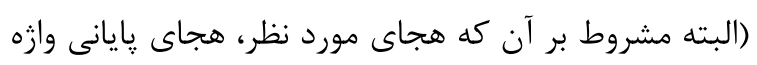

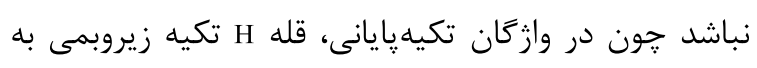

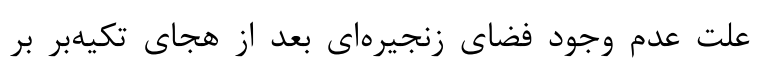

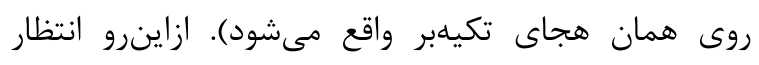

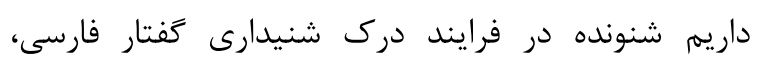

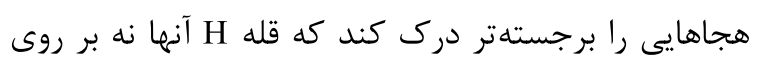
خود بلكه بر روى هجاهاى بعد از آنها واقع شده باشد. از از

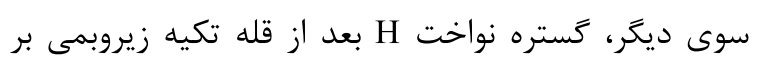

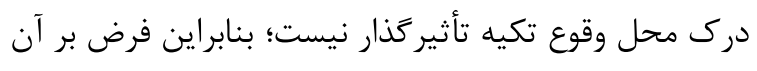

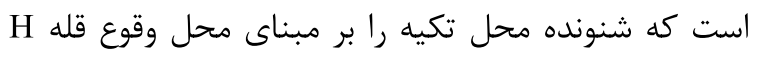

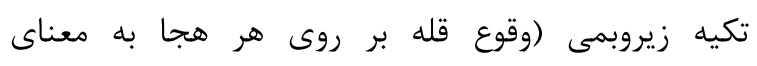
تكيهبر بودن هجاى قبل از آن است) و نه بر مبر مبناى كستره

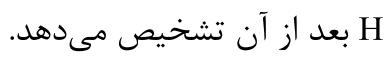

\footnotetext{
${ }^{1}$ Peak delay
}

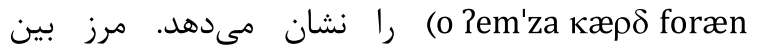

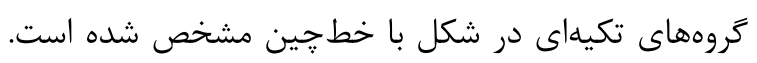

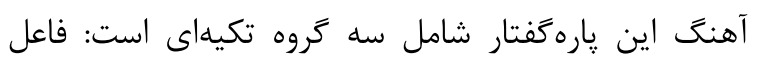

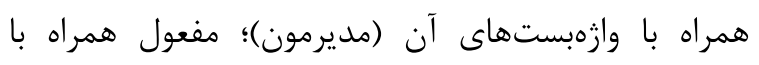

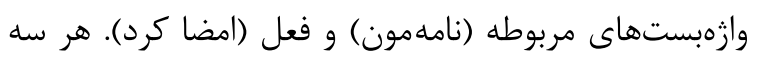
كروه تكيهاى شامل يك تكيه زيروبمي دونواختي

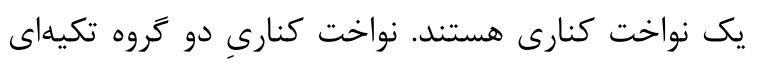

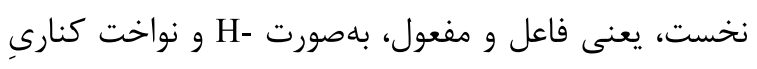

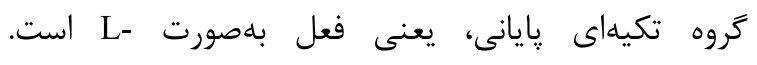

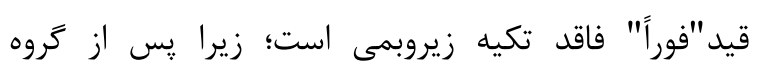
تكيهاى هسته (فعل "امضا كرد") واقع شده است كه نواخت

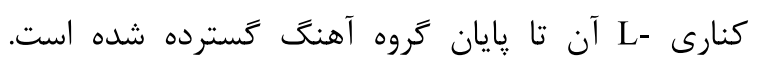

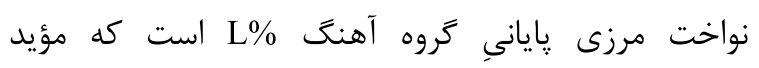
خبرىبودن يارهكفتار است.

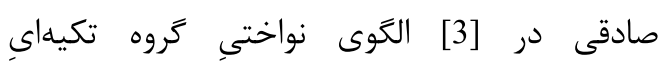

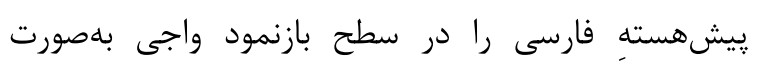

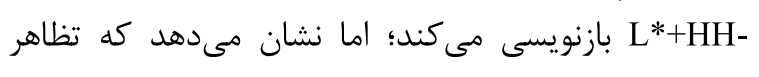
آوايى -H در سطح ييادهسازى آوايى بسته به الكوى تكيه

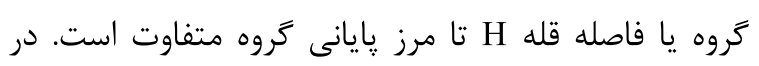

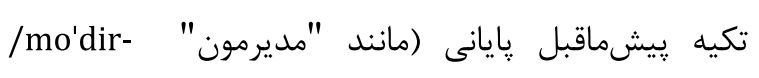
emuin/

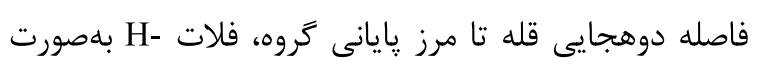

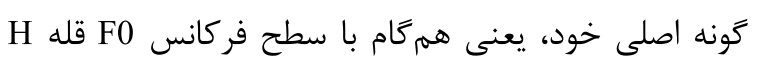

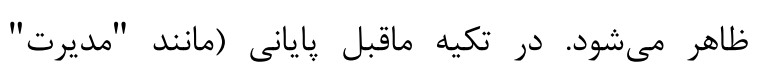

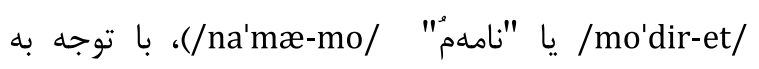

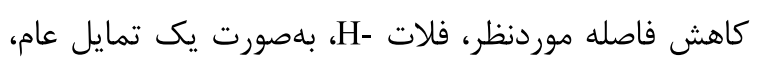

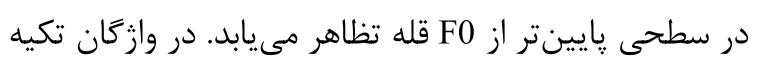

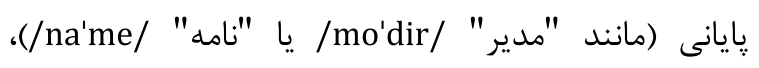
نواخت H- با توجه به نبود فضاى زنجيرهاى كافى تظاهر

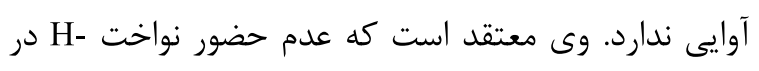

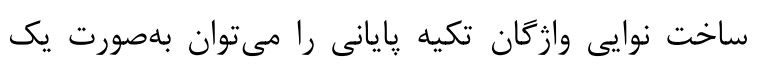

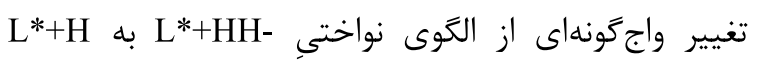

$$
\text { توصيف كرد. }
$$

از ديدكاه آواشناسى، نواخت L تكيه زيروبمى

رِيشهسته، منطبق بر آغاز هجاى تكيهبر و نواخت H

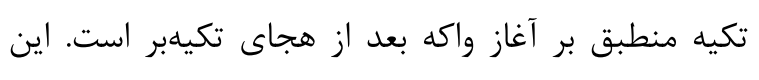
يديده كه نواخت H بلهطوردقيق بر روى زنجيره آوايى

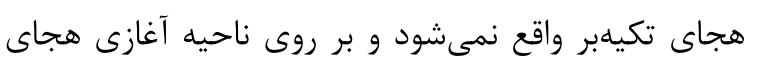

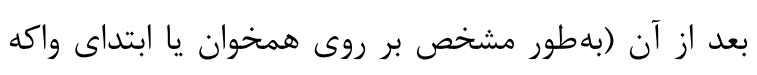


يالسهاى حنجره تبديل و خروجى لايه زيروبمى' اين بازنمود براى إعمال نتظيمات مربوط به فركانس هايه مورد

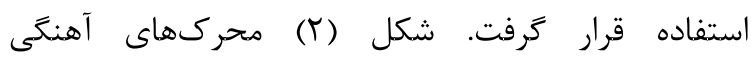
بازسازىشده را نشان مى لـهد.

براى ساخت محرك آهنگیى نخست، كه محرك يايه

براى ساخت محركهاى بعدى بود، يكى تكيه زيروبمى

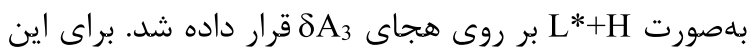
منظور ابتدا مقدار فركانس پِايه زنجيره آوايى

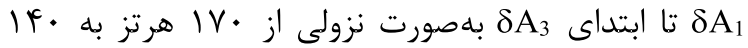
هرتز كاهش داديم؛ سيس فر كانس پِايه را از ابتداى

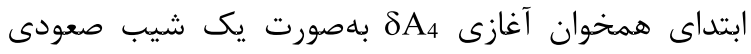

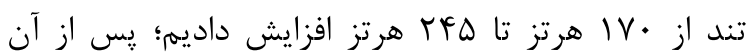
سطح فركانس يايه را از قله H واقع بر روى ابتداى ابتداى SA6 بهصورت يك شيب نزولى بdنسبه تند از هرتز تا • ها هرتز كم كرديه و آن را تا يايان كA

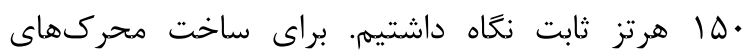
بعدى، يعنى محركهاى دوم تا ششه، دره (L) و قله (H) تكيه زيروبمى را در همان نقاط زنجيرى اصلى (يعنى بلهترتيب در آغاز فركانس H قله تكيه زيروبمى را بهصورت بيوستارى از فواصل زمانى مختلف بر روى توالى هجايى كسترش داديهم تا گسترههايى با سطح ارتفاعى برابر با قله تكيه زيروبمى و طول متفاوت بعد از تكيه زيروبمى H حاصل شود؛ به اين ترتيب كستره H*+H دوم، از ابتداى (همخوان) محرك سوم، از ابتداى (همخوان) هجا؛ براى محرى جهرارم، از ابتداى (همخوان) ابتداى واكه SA5؛ براى محرك ينجمم از ابتداى (همخوان) كAs (همخوان)

\section{r}

در بخش قبل اين كونه بحث كرديم كه با استفاده از محل وقوع قله تكيه زيروبمى و محل وقوع نقطه پِيايانى H (يايان گستره نواخت H) بر روى منحنى مىتوان محل وقوع تكيه

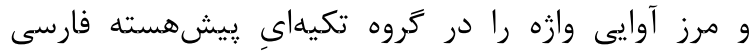
شناسايى كرد. در اين بخش ميزان اعتبار دركى دور ورو يارمتر

${ }^{1}$ Pitch tier

\section{F

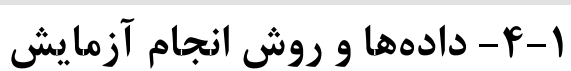

آزمايش نخست، شامل يك آزمون شناسايى دومرحلهاى است كه درك محل وقوع برجستگى نوايى (تكيه) و مرز آوايى وازهه را بهترتيب بهصورت تابعى از محل وقوع قله تكيه زيروبمى و محل وقوع نقطه بِايانى H (يايان كستره نواخت

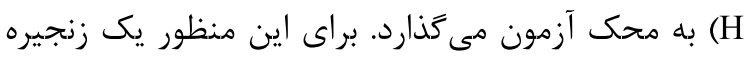

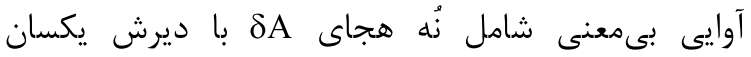
بهنوان محرك هدف آزمايش شنيدارى انتخاب شد. براى ساخت اين توالى هجايى، ابتدا يك هجاى بىمعناى SA توسط يك گوينده بومي زبان فارسي معيار

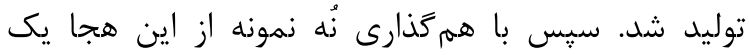

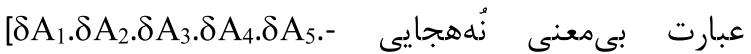

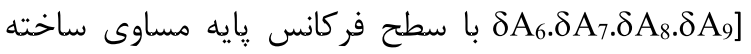

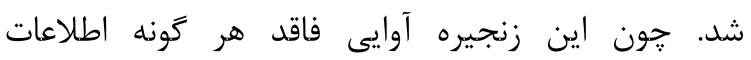
زبانشناختى است، بنابراين فرض بر آن است كه شنون آندونده، تكاليف شنيداري هدف آزمايش را تنها بر مبناى تغييرات زمانبندى وقوع قله تكيه زيروبمى و محل وقوع نقطه بايانى إنى H

با بازسازى الكَى تغييرات فركانس بايه بر روى زنجيرة آوايى

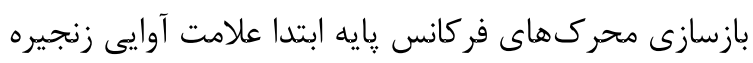

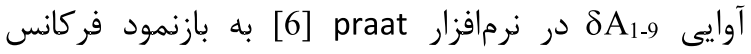



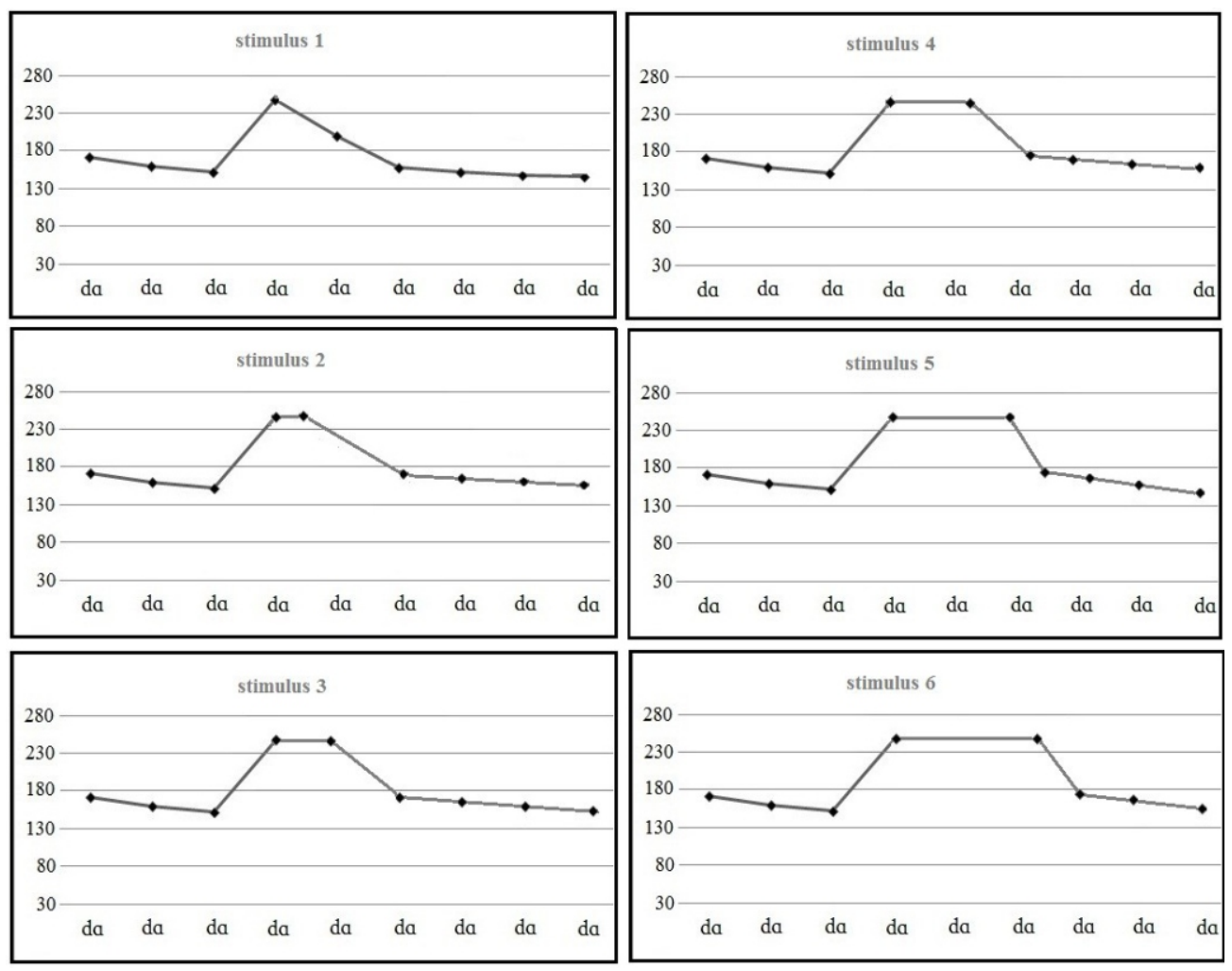

(شكل - (Y): محرك هاى آهنكى ساخته شده از زنجيره آوايى بىمعنى

(Figure-2): intonational stimuli resynthesized from the nonsense syllable string $\delta \mathrm{A}_{1-9}$

شركت كننده يخش و بهازاى هر محرك، درصد ياسخ هر

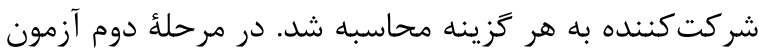

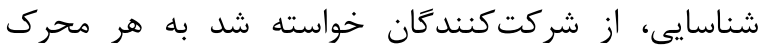
Fوش داده و محل وقوع تكيه را مشخص كرده و رِاسخ صحيح را در يك ياسخنامه بر روى صفحه نمايش شامل سه ززينه هجاى سوم، هجاى جهارم و هجاى ينجم

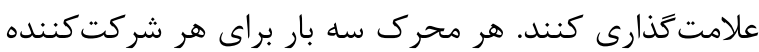
يخش و بهازاى هر محرى تعداد ياسخهاى صحيح هجاى سوم، هجاى جهارم و هجاى ينجم محاسبه شده و بهصورت درصد ياسخهاى صحيح مشخص هُى شد.

\section{(}

شكل (r) نتايج حاصل از آزمون شناسايى براى محركهاى مرحس ييوسته Stimulus1...... Stimulus6 جهت تشخيص مرن وازه نشان مىدهد. در اين شكل، محور X X، محركهاى

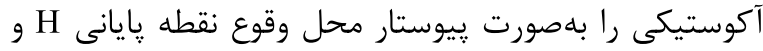

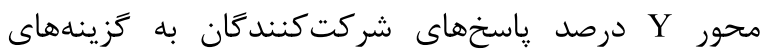

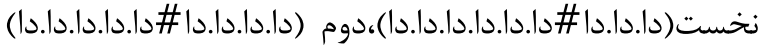

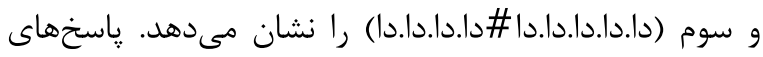
شناسايىشنوندها به ززينههاى نخست-سوم را بهطور جداگانه بررسى مى كنيم.
آهنگ四 محل وقوع قله تكيه زيروبمى و محل وقوع نقطه يايانى H براى تعيين محل برجستخى نوايى و تقطيع وازگكانى كَفتار رييوسته محكى ميى خورد. براى اين منظور يكى آزمون

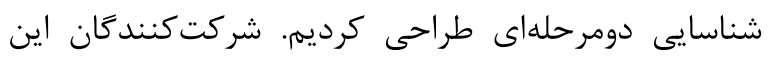
آزمون ده مرد و ده زن فارسىزبانٍ تحصيلكرده بودند. مرحله

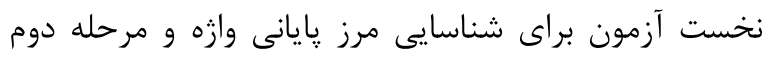
براى شناسايى محل وقوع تكيه در نظر كرفته شد.

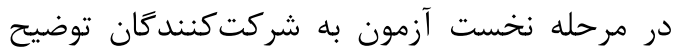

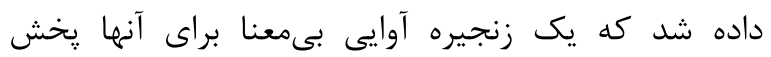

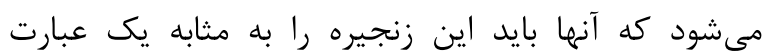

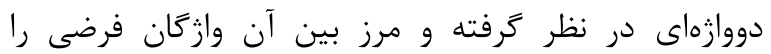
شناسايى كنند؛ سيس، از شركت كنندكان خواسته شد شر تان

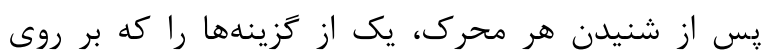
صفحه نمايش با توجه به فرضيههاى مطرحشده در بخش r شامل صورت

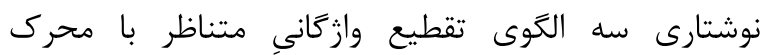

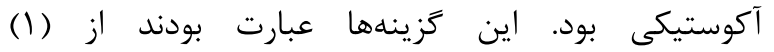

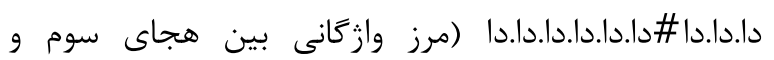

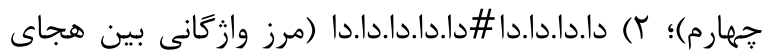

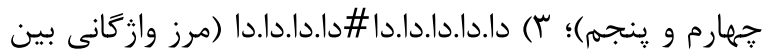

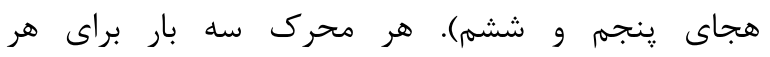


مى كند. پاسخهاى شناسايى به محرك سوم به سطح

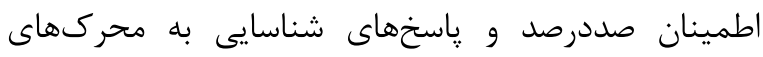
نخست، ينجم و ششم به سطح اطمينان صفردرصد بـ بسيار

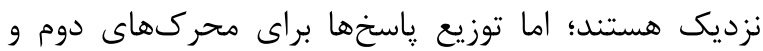

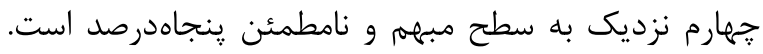

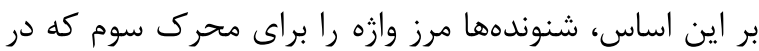
آن قله H تكيه زيروبمى از همخوان آغازى هجاى

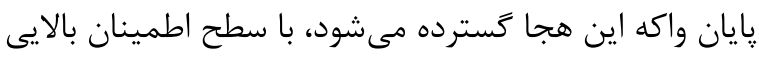
در پايان هجاى סA

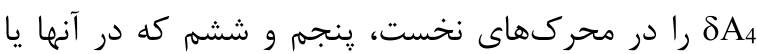

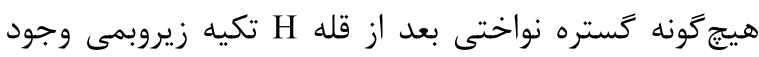
ندارد، (محرك نخست) و يا گستره H تا ابتداى همخوان

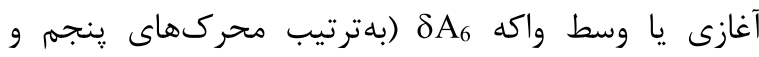
ششم) كشيده شده باشد، بهاحتمال بسيار زياد (نزديك صددرصد) بهعنوان مرز وازگًانى فرضى در نظر نمى

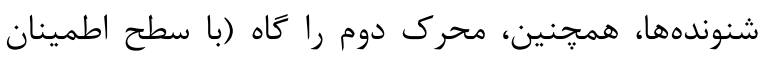

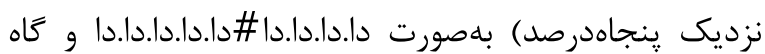

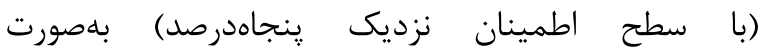

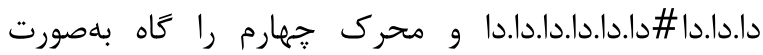

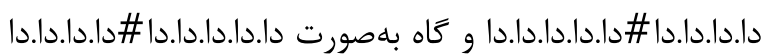
نقطيع مى كنند.

براى كزينه سوم (مرز وازه بين هجاهاى ينجم و إندائ

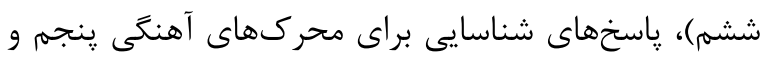

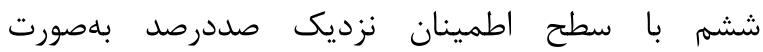

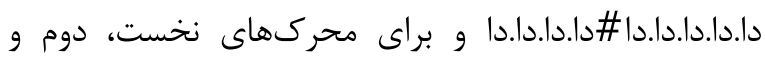

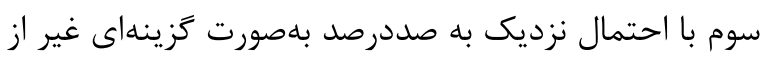

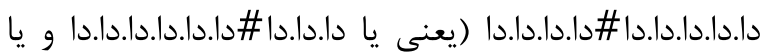

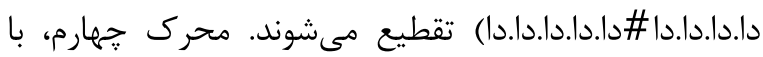

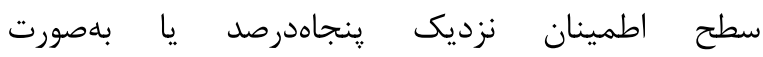

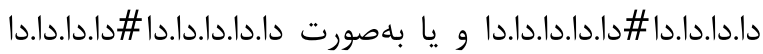

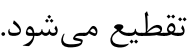
بهطور كلى، نتايج مرحله نخست آزمون شناسايى نشان داد كه شنوندهها نقطه پِيانى گستره نواختى H

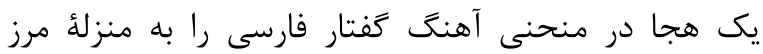

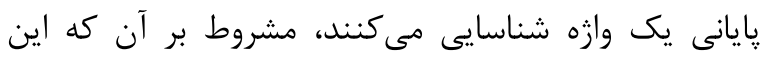

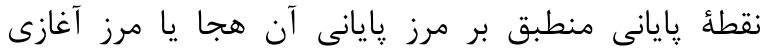

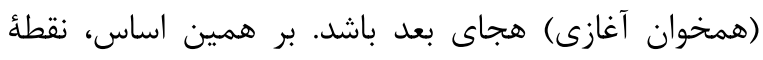

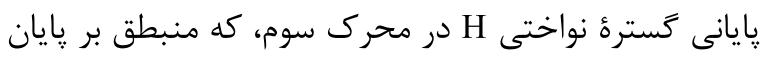
واكه هجاى

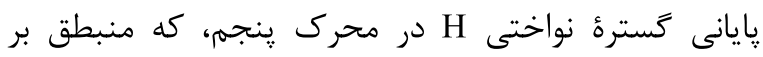

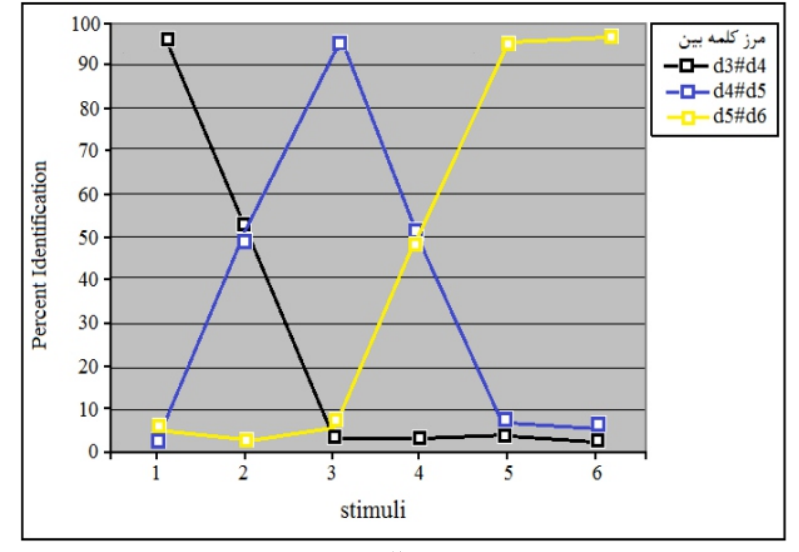

(شكل-r) : نتايج مرحله نخست آزمون شناسايى براى تشخيص

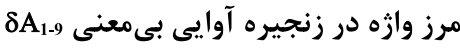

(Figure-3): Results of word boundary identification for the nonsense syllable string $\delta \mathrm{A}_{1-9}$

براى كزينهُ نخست (وجود مرز وازه بين هجاهاى سوم

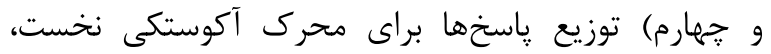

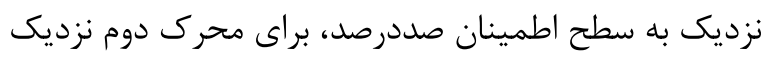

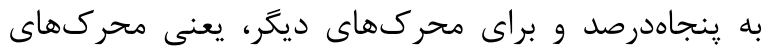

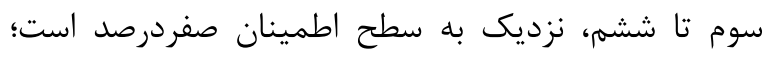

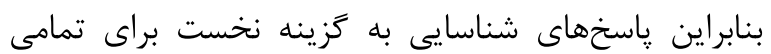
محركها به غير از محرك دوم سطح اطمينان بالايى دارند.

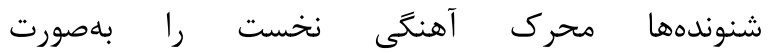

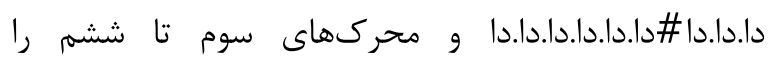

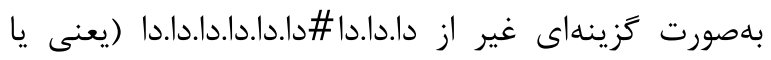

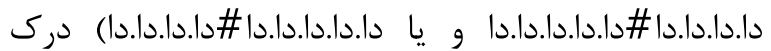

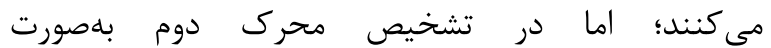

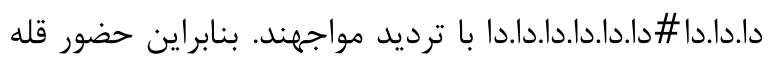

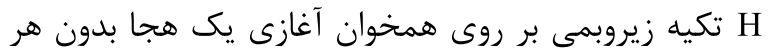

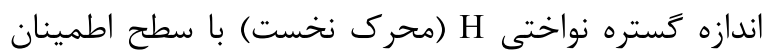

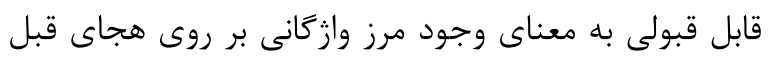

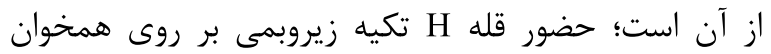

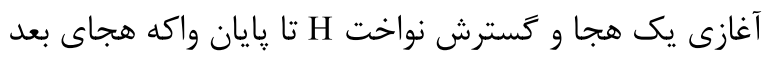

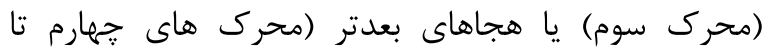

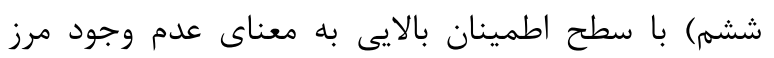

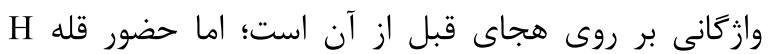

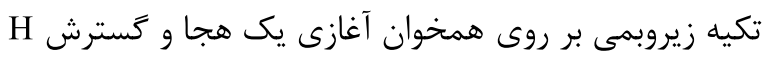

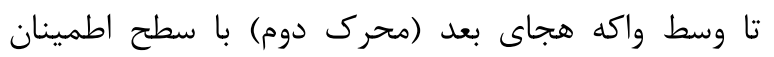

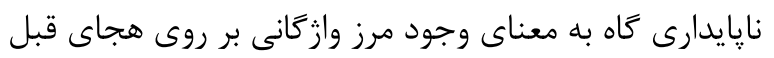

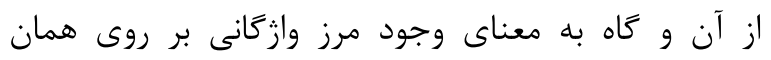
هجاست. منحنى پاسخهاى شناسايى به گزينه دوم (وجود مرز

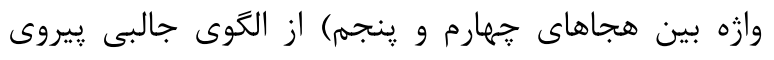


اين واقعيت مؤيد آن است كه شنوندهها هجاى سوم را در زنجيرة آوايى [ بلهنوان برجستهترين هجا درك مى كنند. با توجه به الكوى تغييرات F0 در منحنى آهنگ (بازسازى شده) محركها

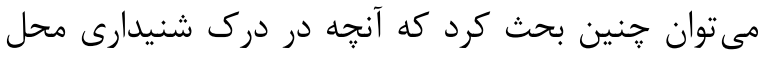
وقوع برجستگى نوايى در يك توالى هجايى اهميت دارد،

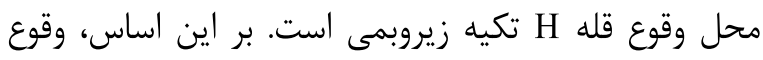
قله H يك تكيه زيروبمى بر روى هر هجا، با توجه وجود

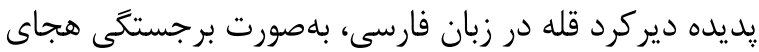

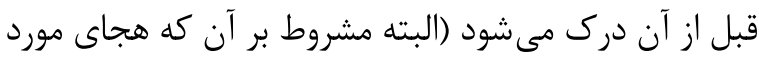

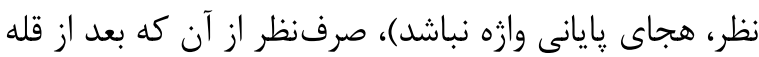

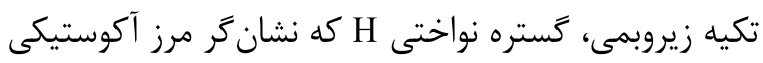

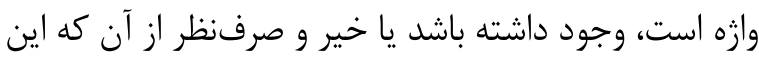
كستره نواختى بر روى جه تعدادى از هجاها كشيده شده

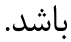

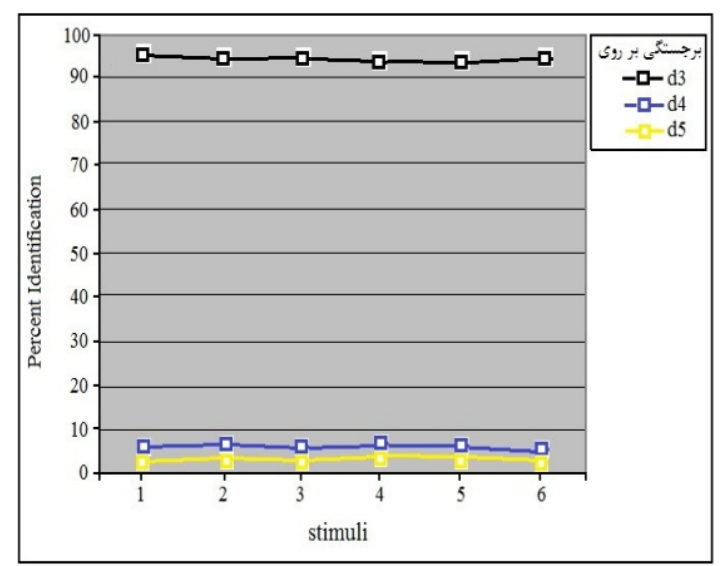

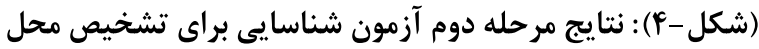

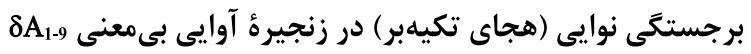
(Figure-4): Results of prominence identification for the nonsense syllable string $\delta \mathrm{A}_{1-9}$

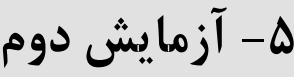

\section{|- إ-ه - دادهها و روش انجام آزمايش}

در آزمايش دوم، درك شنيدارى مرز آكوستيكى وازه بهصورت تابعى از محل وقوع نقطه پايانى H (بايان كستره نواختى H) بر روى زنجيره آوايى عبارات طبيعى فارسى به محكى آزمون كذاشته شد. براى اين منظور تعداد دوازده جمله يا عبارت (كروه) اسمى سلوازماى فارسى بلهعنوان

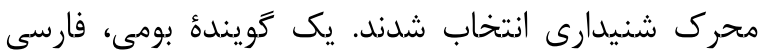
معيار دادهها را با سرعت طبيعى توليد كرد.
پايان واكه هجاى

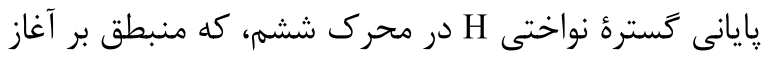
همخوان هجاى

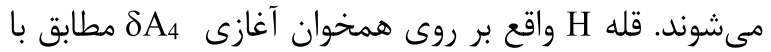

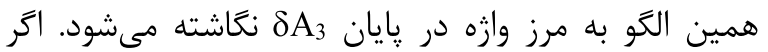

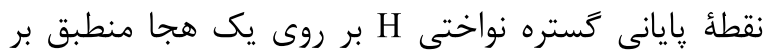

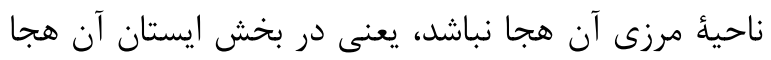
واقع شود، در آنصورت شنونده قادر نيست با سطح اطمينان بالايى مرز وازه را شناسايى كند. در קنين حالتى يا همان

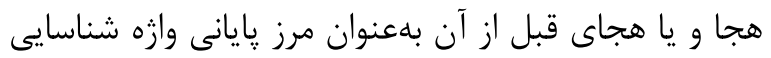

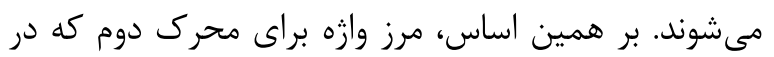

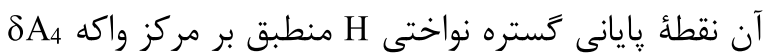
است، كاه پِايان كه در آن نقطه קايانى گستره نواختى واكه $8 A_{5}$ است، كاه يايان

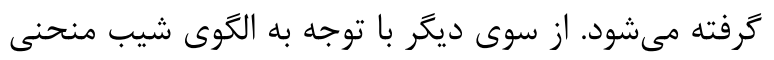

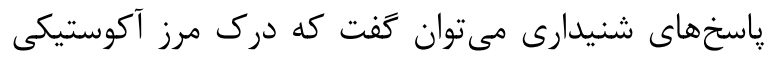

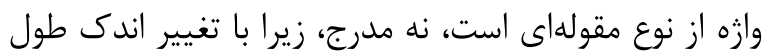

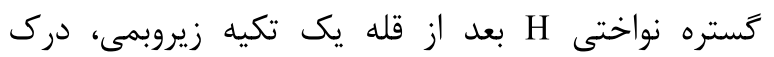

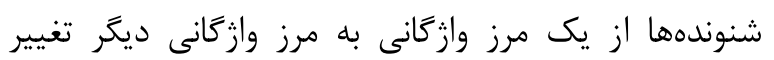
مى كند. البته برخى محر كها (محرك دوم و جهارم) نواحى

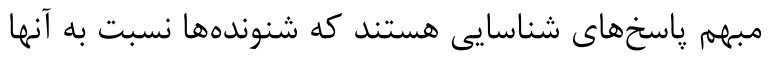

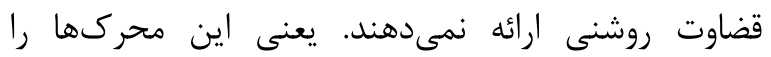
بهصورت يكى از دو مقوله مرز وازَٔانى درك مى كنند.

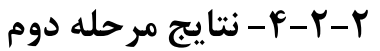

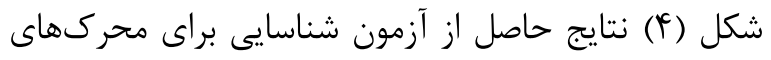

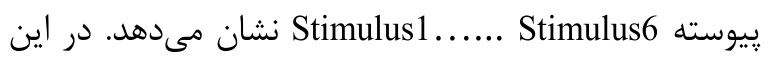

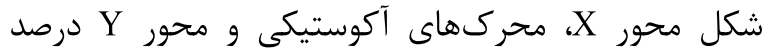

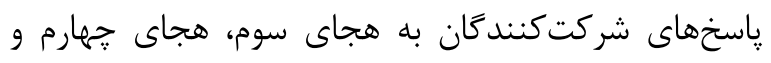
هجاى ينجم را بلعنوان هجاهاى برجسته نشان مىدهد.

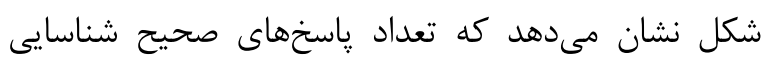
براى هجاى سوم نسبت به هجاهاى جهارم و پينجم برترى

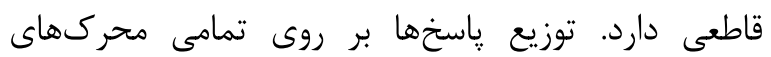

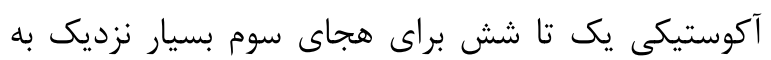

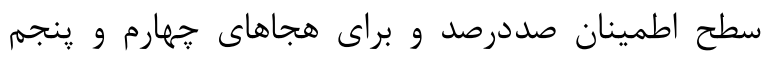
بسيار نزديك به سطح اطمينان صفردرصد است؛ يعنى فاصله

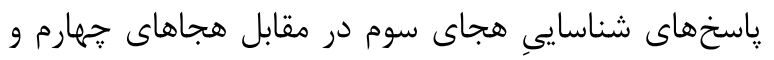

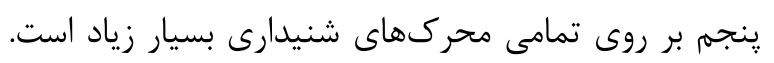



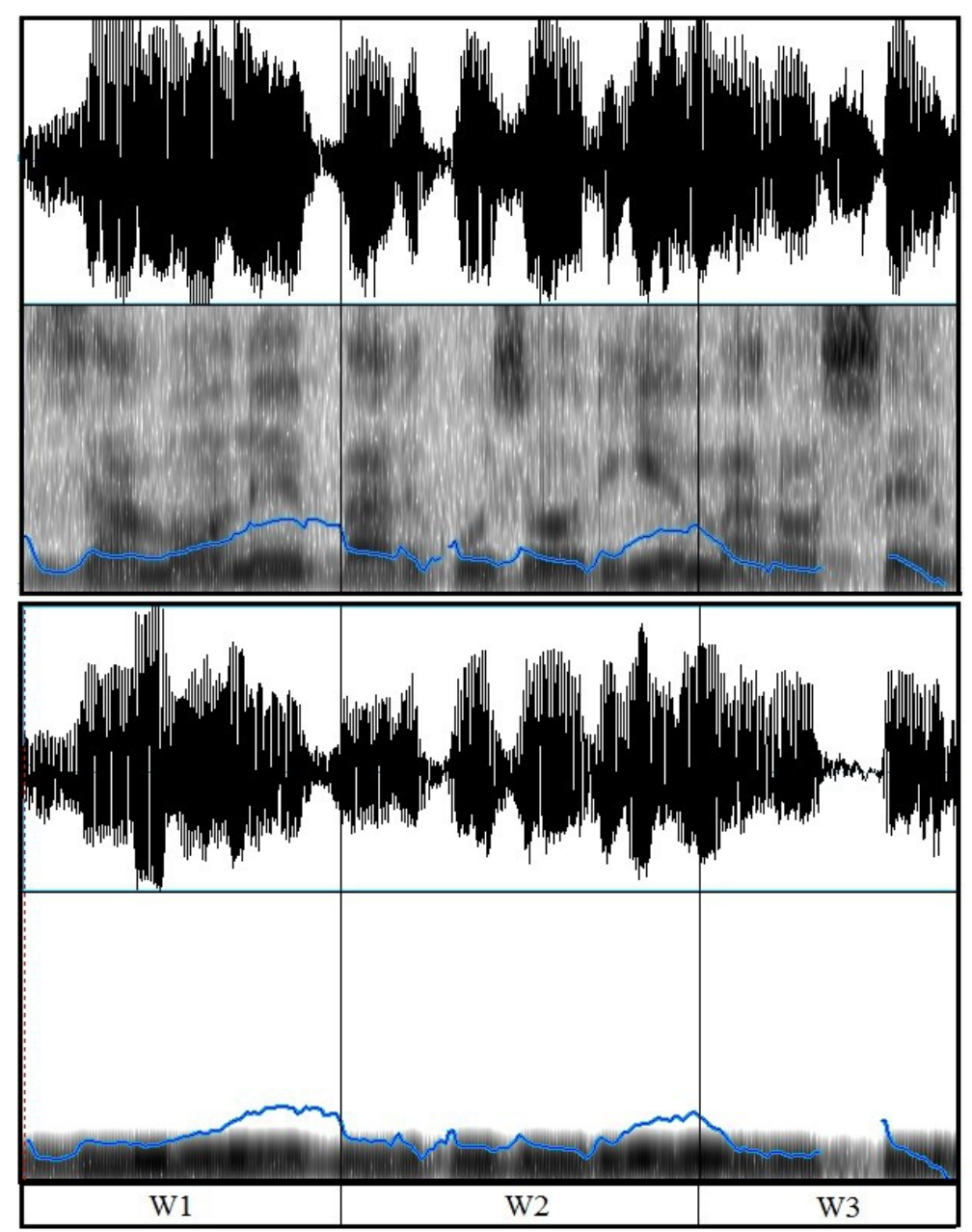

(شكل - ه): سيعنال آوايى، طيفنكاشت و منحنى F0 طبيعى (بالا) و مخدوش شده (پايين) عبارت "زمان بركزارى مراسم". خطوط ممتد

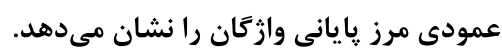

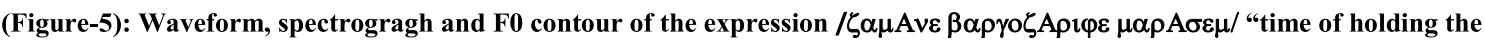
ceremony" in natural (upper panel) and resynthesized (lower panel) forms. Solid lines indicate boundaries between words.

آكوستيكى وازكان بر اساس اين عامل نوايى خنثى شود؛ بر

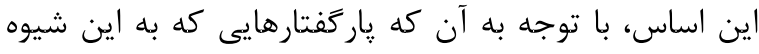

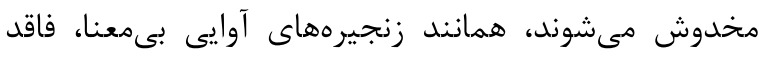
اطلاعات زبانشناختى است، فرض ميى كنيم كه شنونده مرز

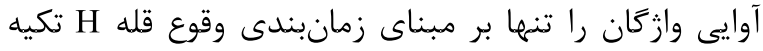

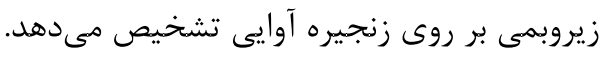

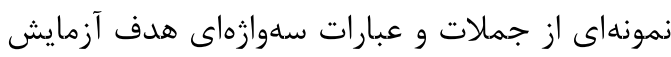

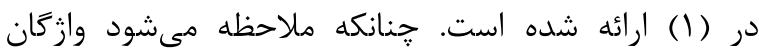
طورى انتخاب شدند تا تمامى بِيجيد

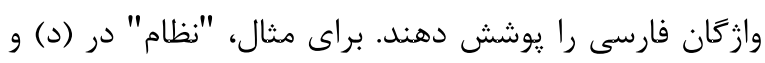

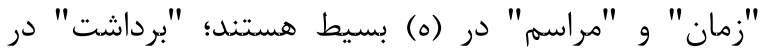

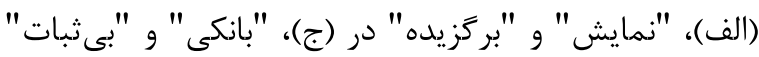

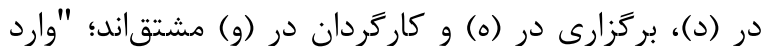

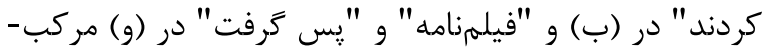

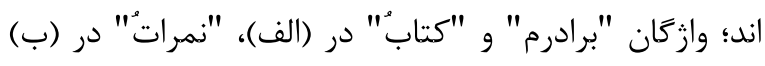

براى اطمينان از آن كه شنوندهها مرز آكوستيكى

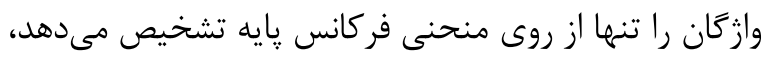

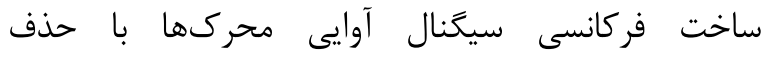
فركانسهاى بالاى سيصد هرتز' مخدوش شد تا شنونده به اطلاعات زبانشناختى سيخنالها دسترسى نداشته باشد

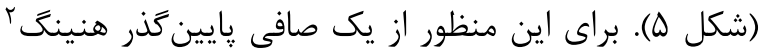
با فر كانس قطع سيصد هرتز و سطح هموارسازى ينجاه هرتز استفاده و هر كونه وقفه زمانى اضافى ناشى از مكث بين وازگًان در كفتار كوينده حذف شد تا احتمال شناسايى مرز ' دامنه زيروبمى صداى گوينده بين هو تا هو9 أهرتز بود.

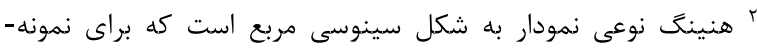

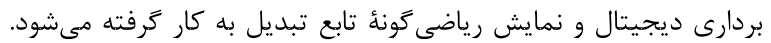

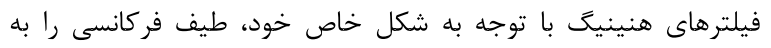

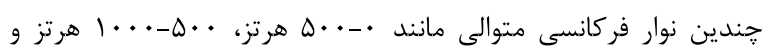
غيره تبديل مى كنند. 
بايد يس از شنيدن آن در كفتار خود بازتوليد (به تعداد

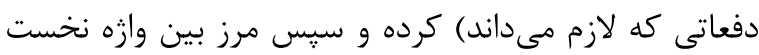

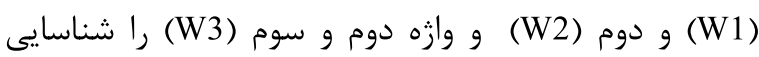

كند (حدس بزند).

$$
\text { - }
$$

هر يارهَفتار مخدوش شده سه بار براى هر شنونده پخش و

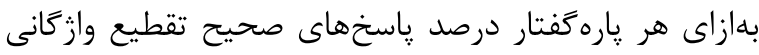

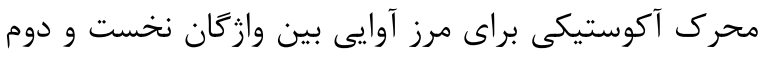

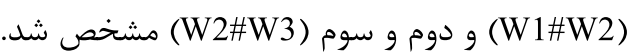

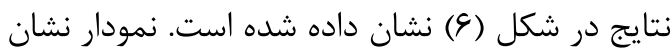
مى دهد كه شنوندهها در MA. موارد مرز آكوستيكى بين وازثه

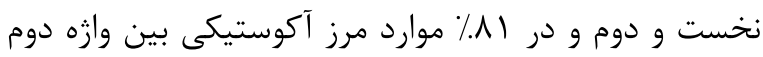

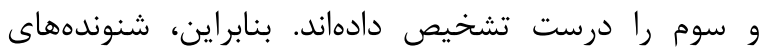
فارسى حتى در صورت تخريب ساخت فركانسى سيخنال

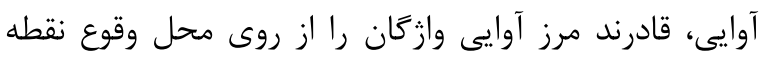
يايانى خيز زيروبمى تشخيص دهند.
حامل وازهبست هستند، ضمن آن كه وازَّان "نمايشِ"،

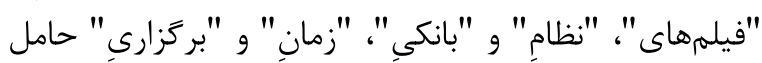
وازهبست كسره اضافه در ساختهاى اضافىاند؛ و بالاخره اين

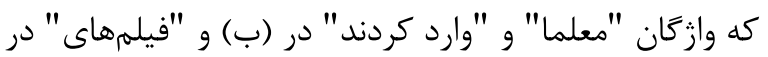

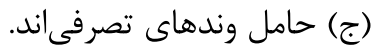
(1) الف: برادرم كتابُ برداشت.

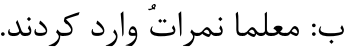
ج: إيش فيلمهاى بركزيده

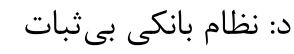

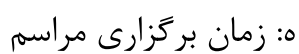

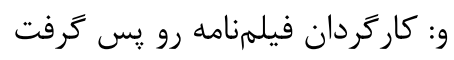

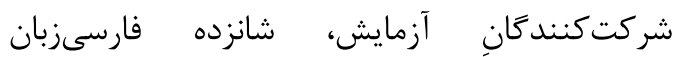
تحصيل كرده (هشت مرد و هشت زن) بودند إندان يارهَّفتارهاى

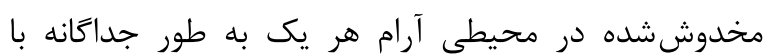

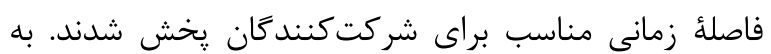

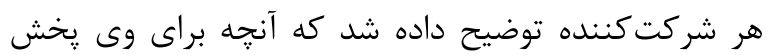

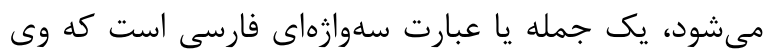

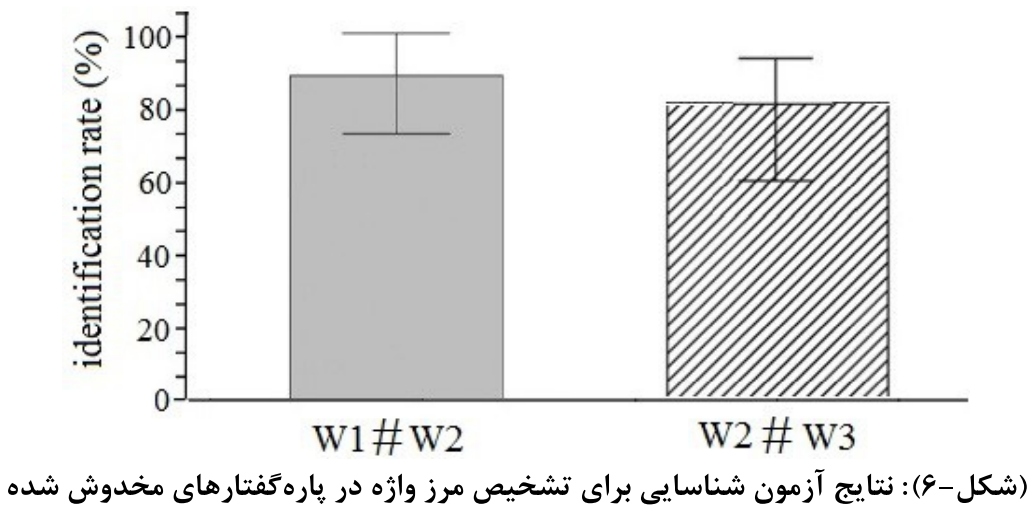

(Figure-6): Results of word boundary identification for resynthesized speech

است (واز5ان فاقد وازّبست) و يا منطبق بر ناحيهاى است

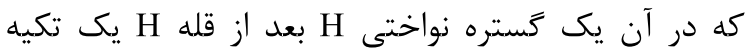
زيروبمى به انتها رسيده باشد (وازَان حاوى وازٔمبست). بر

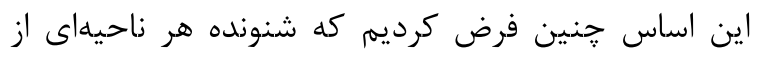
منحنى آهنَ كَفتار فارسى را كه در آن نواخت H به به بايان خيز (در صورت عدم وجود گستره نواختى H بعد از از تكيه

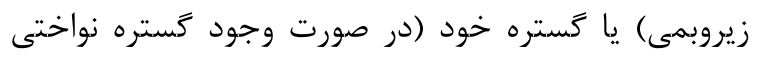

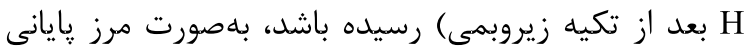

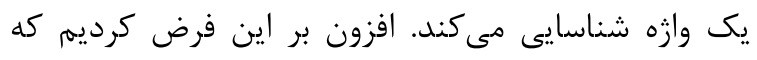
جون قله H تكيه زيروبمى بيشهسته فارسى در وازئان

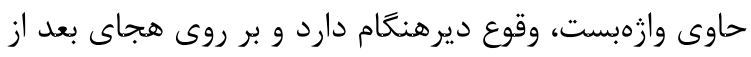

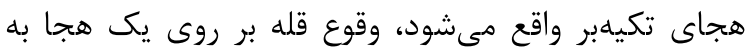

\section{9- نتيجه كيرى و بحث}

در يزوهش حاضر نقش محل وقوع قله تكيه زيروبمى و

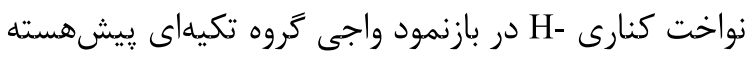
فارسى را بهترتيب در شناسايى محل وقوع برجستكى نوايى كاري

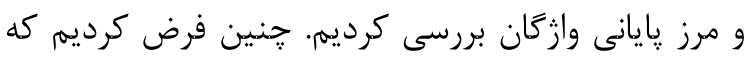

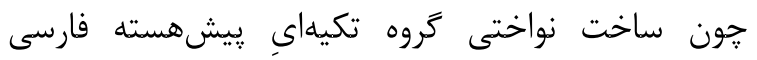

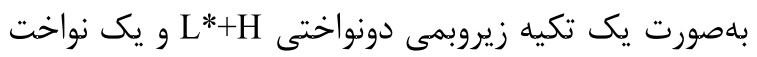

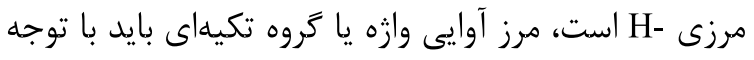

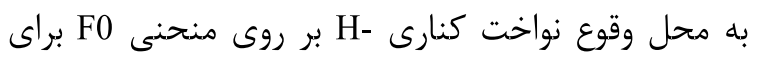

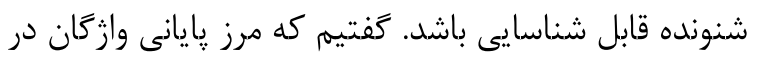

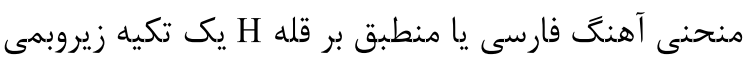


نتايج مرحله دوم آزمون شناسايى نشان داد كه آنجه

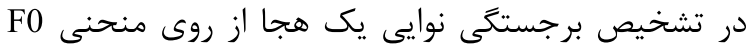

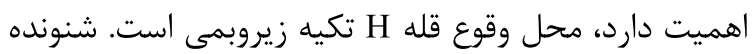

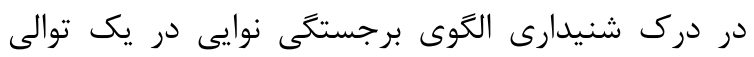

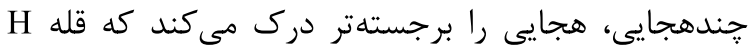

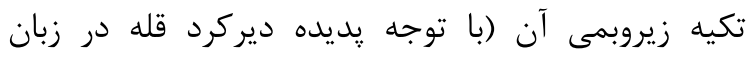

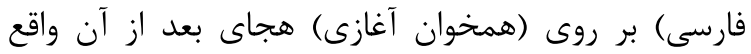

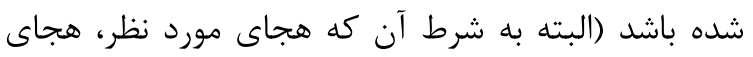

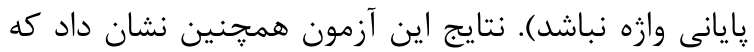

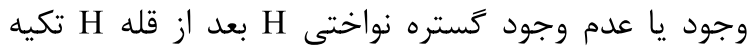

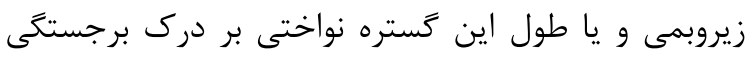

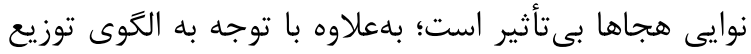

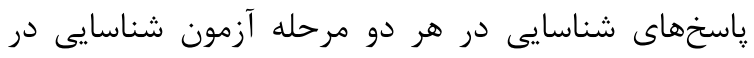

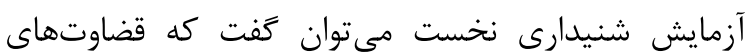
شنيدارى شنوندها درباره محل وقوع مرز آكوستيكى وازه و

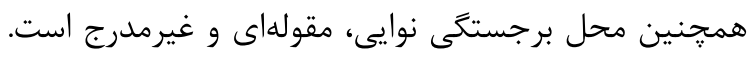

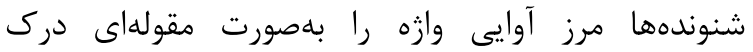

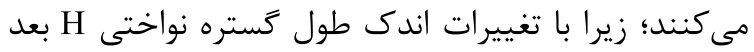
از قله يك تكيه زيروبمى، درك شنوندهاتها از يكى مرز

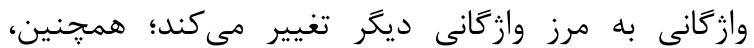

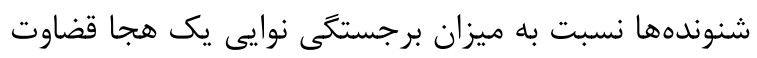

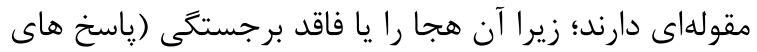

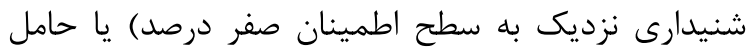

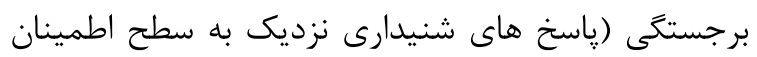

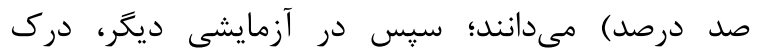

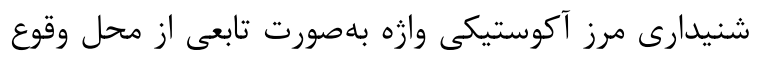

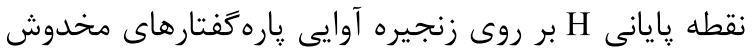

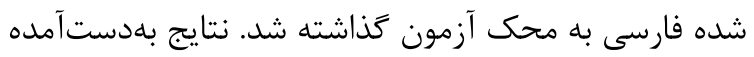

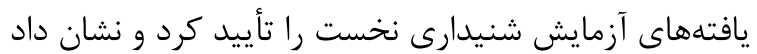

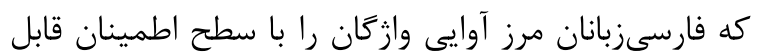

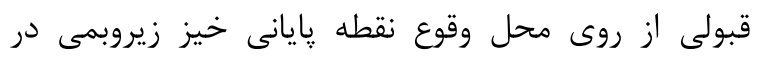

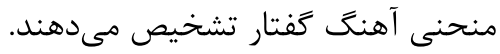

با مقايسه نتايج يزوهش حاضر با يافتههاى بيشين

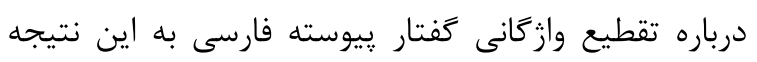
مىرسيم كه با وجودى كه حضور تكيه در جايخاه غير يايانى

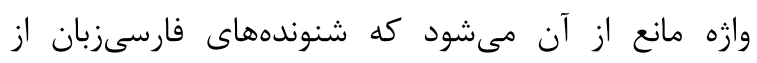

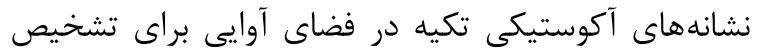
مرز آكوستيكى وازّكان استفاده كنند، اما مرز يايانى وازيهها

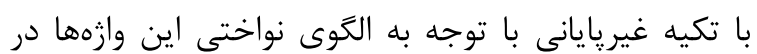

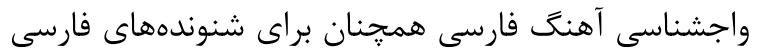

معناى برجستگى هجاى قبل از آن است و به همين دليل

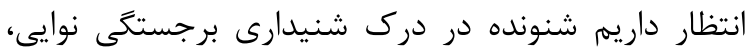

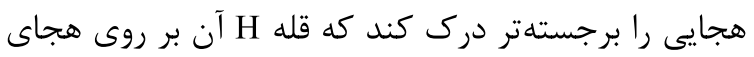
بعد از آن واقع شده باشد. براى ارزيابى ميزان اعتبار يارامتر آكوستيكى محل

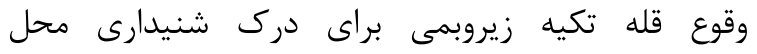

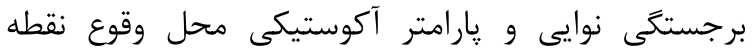

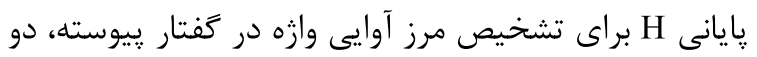

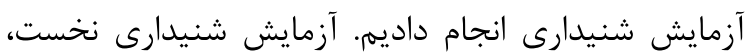

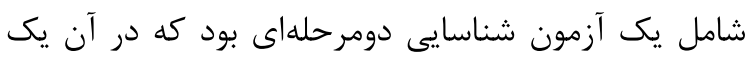

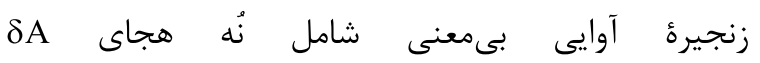

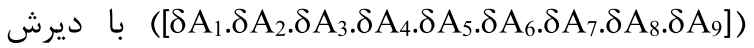
يكسان بهعنوان محرى شنيدارى مورد استفاده قرار ترفت.

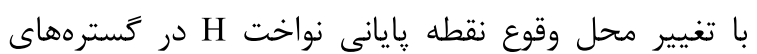

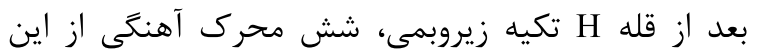

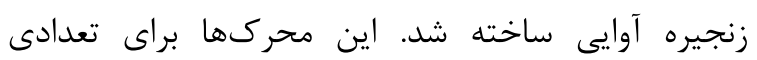

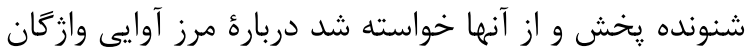

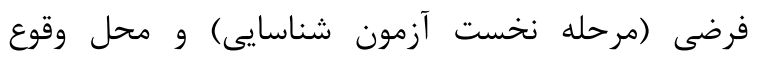
برجستىى نوايى (مرحله دوم آزمون شناسايى) در زنجيزه آوايى مورد نظر تصميمى خيرى كنئد.

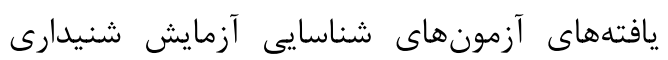

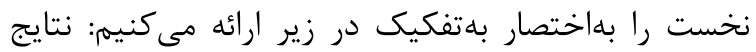

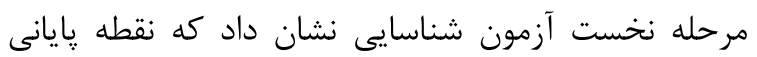

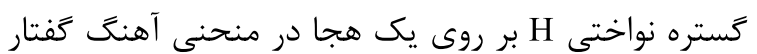

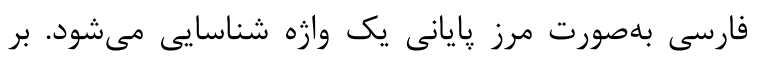

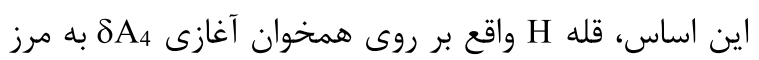

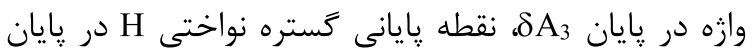

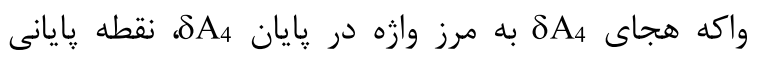

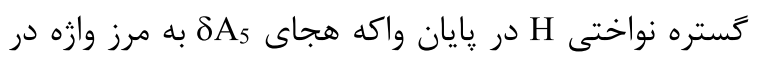
بايان

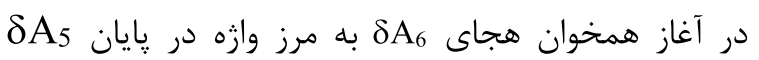
نخاشته مىشوند. اكر نقطه پِايانى كستره نواختى بخش ايستان يك هجا (و نه مرز هجا) واقع شود، در آنى ناني

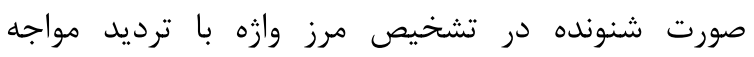
مىشود. در اين وضعيت، وى يا همان هجا و يا هجاى قبل

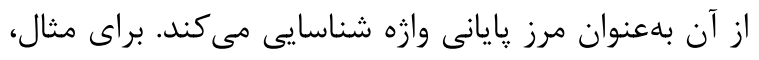

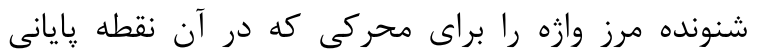
كستره نواختى H منطبق بر مركز واكه

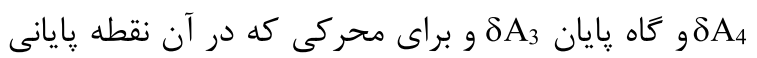
كستره نواختى H منطبق بر مركز واكه

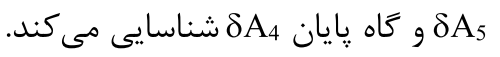


[9] A. Cutler and D. M. Carter, "The predominance of strong syllables in English vocabulary" Computer Speech and Language, vol.2, pp.133-142, 1987.

[10] A. Cutler and J. M. McQueen, "How prosody is both mandatory and optional," in Above and Beyond the Segments: Experimental Linguistics and Phonetics, J. Casper, Y. Chen, W. Heeren, J. Pacilly, N. O. Schiller, and E. van Zanten (eds.). Amsterdam: Benjamins, pp. 7182, 2014.

[11] A. Golard, E. Sommerfield, and F. Kugler, "Prosodic cue weighting in disambiguation: Case Ambiguity in German", The Fifth International Conference on Speech Prosody. Michigan, USA, pp.165-169, 2010.

[12] L. M. Hyman, "Do all languages have word accent?" In van der Hulst, H. (ed.) Word Stress: Theoretical and Typological Issues. Cambridge: Cambridge University Press, 2014. DOI: $10.1017 /$ cbo9781139600408.004

[13] M. H. K. Ip and A. Cutler, "Crosslanguage data on five types of prosodic focus," Proceedings of Speech Prosody, 2016.

[14] M. H. K. Ip and A. Cutler, "Intonation facilitates prediction of focus even in the presence of lexical tones," Proceedings of Interspeech, pp. 1218-1222, 2017.

[15] M. Moneglia, \& T. Raso, "Notes on Language into Act Theory (L-AcT)". In T. Raso \& H.R. Mello (eds), Spoken Corpora and Linguistic Studies, Amsterdam/Philadelphia: John Benjamins, pp.468-494, 2014.

[16] M. M. Mittman and P. Barbosa, “An automatic speech segmentation tool based on multiple acoustic parameters", Romance Corpora and Linguistic Studies 3.2, pp.133-147, 2016.

[17] B. Mahjani, “An instrumental study of prosodic features and intonation in Modern Farsi (Persian)". MS thesis, 2003. Retrieved from: http://www.ling.ed.ac.uk/teaching/postgrad/ms cslp/archive/dissertations/20023/behzad_mahja ni.pdf.

[18] S. L. Mattys, "Stress versus co-articulation: towards an integrated approach to explicit speech segmentation" Journal of Experimental Psychology, vol.30, pp.397-40, 2004. DOI: 10.1037/0096-1523.30.2.397

[19] T. Raso, \& H. Mello, "Description, Methodology and Theoretical Framework". In T. Berber Sardinha \& T. L. São Bento (eds), Working with Portuguese Corpora. London: Bloomsbury, pp.257-278, 2014.

[20] T. Raso, M. Mittmann, \& M. Mendes, "O papel da pausa na segmentação prosódica de corpora
7- References

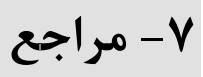

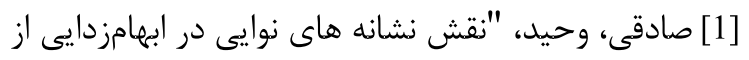

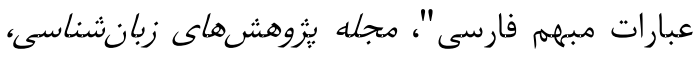

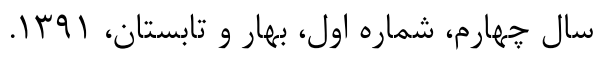

[1] V. Sadeghi, "The role of prosodic cues in disambiguting Persian expressions", Journal of Lingusiatic Researches, 1(2), 2012.

$$
\begin{aligned}
& \text { [2] صادقى، وحيد، "طراحى و ارزيابى يك سامانهُ بازسازى }
\end{aligned}
$$

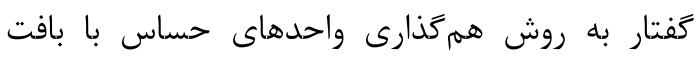

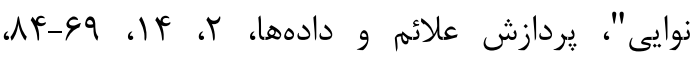$$
.1 \% 19
$$

[2] V. Sadeghi, "Design and Evaluation of a Persian TTS system using prosodically-sensitive concatenative units", Journal of Signal and Data Processing, vol.2, no.14, pp.69-84, 2010.

$$
\begin{aligned}
& \text { [3] صادقى، وحيد، ساخت نوايى زبان فارسى، سازمان }
\end{aligned}
$$

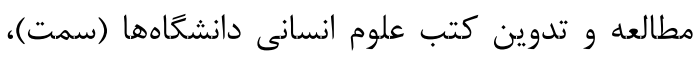

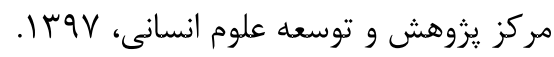

[3] V. Sadeghi, Persian prosodic structure, The Iranian Center for Research and Development in the Humanities, 2018.

$$
\begin{aligned}
& \text { [4] محمدى، مينا و بىجنخان، محمود، "بررسى } \\
& \text { فرايندهاى شناختى كودكان فارسى زبان در بازشناسى }
\end{aligned}
$$

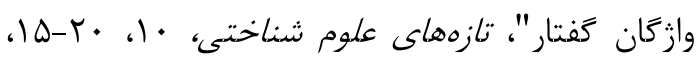$$
.1 \% \text {. }
$$

[4] M. Mohammadi and M. Bijankhan, "The study of children's cognitive processes in spoken word recognition", Recent Findings in Cognitive Sciences, vol.10, 2001, pp.15-20.

[5] P. Barbosa, "Prominence- and boundary-related acoustic correlations in Brazilian Portuguese read and spontaneous speech", Proceedings of Speech Prosody, pp. 257-260, 2008. Campinas, Brazil.

[6] P. Boersma, \& D. Weenink, "Praat: doing phonetics by computer [Computer program]", Version 4.3.01, Retrived from http://www.praat.org/, 2010.

[7] A. Cutler, "Lexical stress", In D. B. Pisoni \& R. E. Remez (Eds.), The handbook of speech perception (pp. 264-289). Oxford, UK: Blackwell, 2005.

[8] A. Cutler and S. Butterfield, "Rhythmic cues to speech segmentation", Journal of Memory and Language, vol. 31, pp.218-236, 1992 DOI: 10.1016/0749-596x(92)90012-m 
de fala. Revista de Estudos da Linguagem" vol.23 (3), pp.883-922, 2015.

[21] N. Sadat-Tehrani, "The Intonational Grammar of Persian", PhD thesis. University of Manitoba, 2007.

[22] N. Sadat-Tehrani, "The alignment of $\mathrm{L}+\mathrm{H}^{*}$ pitch accents in Persian intonation", Journal of the International Phonetic Association, 39, 205-230., 2009. DOI: 10.1017/s0025100309003892

[23] V. Sadeghi, "The timing of pre-nuclear pitch accents in Persian", Journal of the International Phonetic Association, 2017.

[24] S. M. Spitzer, J. Liss and S. L. Mattys, "Acoustic cues to lexical segmentation: A study of resynthesized speech", Journal of the Acoustical Society of America, vol.122, pp. 3678-3687, 2007. DOI: 10.1121/1.2801545.

[25] J. Vroomen, M. van Zon \& B. de Gelder, "Cues to speech segmentation: Evidence from juncture misperceptions and word spotting", $\mathrm{Me}$ mory \& Cognition, vol.24, pp.744-55 1996. DOI: $10.3758 / \mathrm{bf03201099.}$

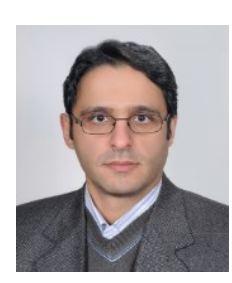

وحيد صادقى متولد سال سهrا است.

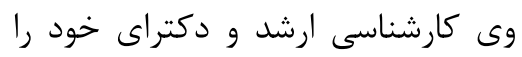

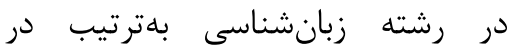

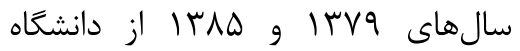
تهران اخذ كرده است. ايشان در حال

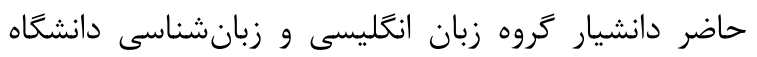

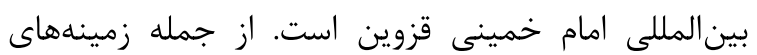

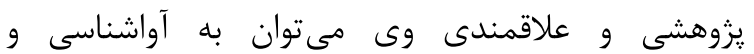
واجشناسى و يردازش سيخَالهاى آوايى اشاره كرد. نشانى رايانامه ايشان عبارت است ازئ vsadeghi@hum.ikiu.ac.ir 
